
HETEROCYCLES, Vol. 87, No. 11, 2013, pp. 2225 - 2248. @ 2013 The Japan Institute of Heterocyclic Chemistry
Received, 11th September, 2013, Accepted, 4th October, 2013, Published online, 10th October, 2013 DOI: 10.3987/REV-13-782

\title{
RECENT SYNTHESES OF PROANTHOCYANIDINS
}

\section{Hidefumi Makabe*}

\author{
${ }^{a}$ Sciences of Functional Foods, Graduate School of Agriculture, Shinshu \\ University, 8304 Minami-minowa, Kami-ina, Nagano 399-4598, Japan
}

\begin{abstract}
Recently proanthocyanidins have been paid much attention due to their significant biological activities and health benefitical effects. The author reviewed recent progress of the syntheses of proanthocyanidins including our work within this decade.
\end{abstract}

\section{INTRODUCTION}

Proanthocyanidins are known as condensed or non-hydrolysable tannins whose structures are basically consisted of flavan-3-ols. ${ }^{1}$ These compounds are widely distributed in the vegetables, fruits and plant-originated beverage such as tea and wines. ${ }^{2}$ Proanthocyanidins have been reported to exhibit strong free-radical scavenging and antioxidative activities. ${ }^{3}$ Many significant biological activities such as antitumor, ${ }^{4,5}$ antiviral, ${ }^{6}$ anti-inflammatory, ${ }^{7}$ and the inhibition of DNA polymerase were reported. ${ }^{8}$ Thus proanthocyanidins are increasingly recognized as possessing health beneficial effects for humans. There are various type of proanthocyaidins in the nature. The large structural diversity of these compounds exhibits various types of the configurational differences such as C-3- and C-4 stereocenter and the regioisomers and stereochemistries of the inter-flavan bonds. Because their identification as well as purification is extremely difficult even using modern methods of isolation technique such as HPLC and UPLC, further investigation of the biological activities, i. e. mechanism of action of bioactivities remains unknown. In these days, in order to obtain pure proanthocyanidins, synthetic studies have been devoted. ${ }^{9-11}$ As a result, some of total syntheses of procyanidins have been accomplished and their biological activities and their structure-activity relationship studies have been begun to be reported. However, the syntheses of high degree of oligomerised proanthocyanidins are still difficult although the degree of polimerization was reported to be enhanced biological activities. ${ }^{12,13}$ Here the author wish to introduce the recent synthetic approaches toward procyanidins and prodelphinidins (Figure 1,2). 
<smiles>Oc1cc(O)c2c(c1)O[C@H](c1ccc(O)c(O)c1)C(O)C2</smiles><smiles>Oc1cc(O)c2c(c1)O[C@H](c1ccc(O)c(O)c1)[C@H](O)C2</smiles>

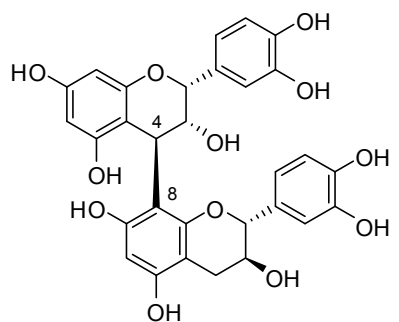

procyanidin B1 (1)<smiles>Oc1cc(O)c2c(c1)O[C@H](c1ccc(O)c(O)c1)[C@H](O)C2c1c(O)cc(O)c2c1O[C@H](c1ccc(O)c(O)c1)[C@H](O)C2</smiles>

procyanidin B2 (2)<smiles>Oc1cc(O)c2c(c1)O[C@H](c1ccc(O)c(O)c1)C(O)[C@H]2c1c(O)cc(O)c2c1O[C@H](c1ccc(O)c(O)c1)[C@H](O)C2</smiles>

procyanidin B3 (3)<smiles>Oc1cc(O)c2c(c1)O[C@H](c1ccc(O)c(O)c1)[C@H](O)[C@H]2c1c(O)cc(O)c2c1O[C@H](c1ccc(O)c(O)c1)[C@H](O)C2</smiles>

procyanidin B4 (4)<smiles>Oc1cc(O)c2c(c1)O[C@H](c1ccc(O)c(O)c1)[C@H](O)[C@H]2O</smiles><smiles></smiles><smiles>Cc1ccccc1O</smiles><smiles>Oc1cc(O)c2c(c1)O[C@H](c1ccc(O)c(O)c1)[C@H](O)C2c1c(O)cc(O)c2c1O[C@H](c1ccc(O)c(O)c1)[C@H](O)C2c1c(O)cc(O)c2c1O[C@H](c1ccc(O)c(O)c1)C[C@H]2O</smiles>

procyanidin C1 (5)<smiles>Oc1cc(O)c2c(c1)O[C@H](c1ccc(O)c(O)c1)[C@H](O)[C@H]2c1c(O)cc(O)c2c1O[C@H](c1ccc(O)c(O)c1)[C@H](O)[C@H]2c1c(O)cc(O)c2c1O[C@H](c1ccc(O)c(O)c1)C[C@@H]2O</smiles>

procyanidin C2 (6)<smiles>OCCOCCO</smiles>

catechin tetramer (8)

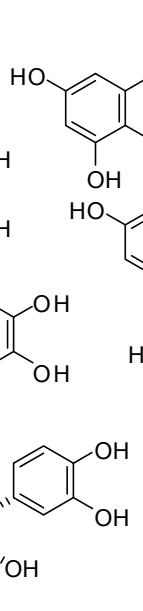<smiles>C=C(O)C[C@H](CO)Cc1c(O)cccc1OC(C)c1ccc(O)c(O)c1</smiles><smiles>C=C(O)C(C)C(CO)COc1c(O)cc(O)c2c1O[C@H](c1ccc(O)c(O)c1)C(O)C2Cc1c(O)cc(O)c2c1O[C@H](c1ccc(O)c(O)c1)[C@H](O)C2</smiles>

cinnamtannin A2 (7)
$\mathrm{OH}^{\mathrm{OH}}$

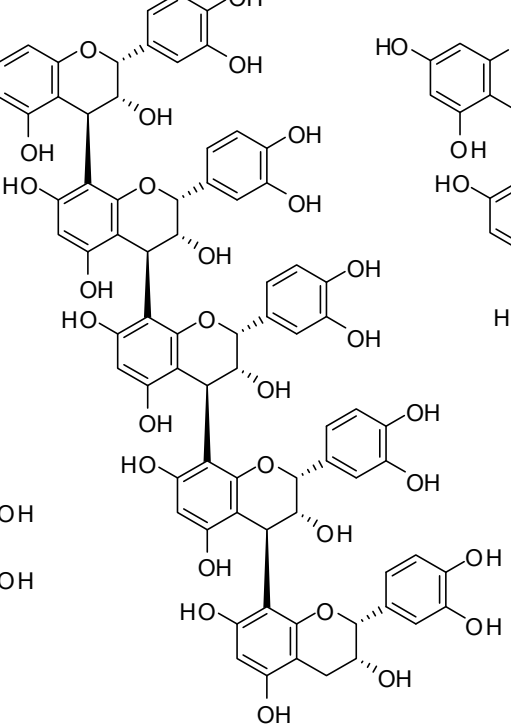

cinnamtann in A3 (9)<smiles>C[C@@H]1Cc2ccc(O)c([C@H]3c4c(O)cc(O)cc4O[C@H](c4ccc(O)c(O)c4)[C@@H]3O)c2O[C@@H]1c1ccc(O)c(O)c1</smiles>

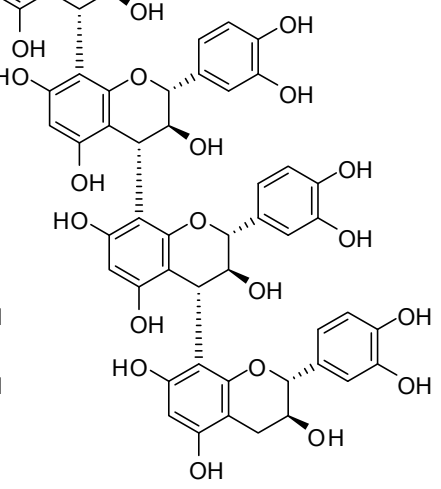

catechin pentamer (10)

Figure 1. The structures of procyanidins 
<smiles>Oc1cc(O)c2c(c1)O[C@H](c1cc(O)c(O)c(O)c1)[C@H](O)C2</smiles>

gallo catechin<smiles>Oc1cc(O)c2c(c1)O[C@H](c1cc(O)c(O)c(O)c1)[C@H](O)C2</smiles>

epigallocatechin<smiles>Oc1cc(O)c2c(c1)O[C@H](c1cc(O)c(O)c(O)c1)[C@H](O)[C@H]2c1c(O)cc(O)c2c1O[C@H](c1cc(O)c(O)c(O)c1)[C@H](O)C2</smiles>

prodelphindidin B1 (12)<smiles>Oc1cc(O)c2c(c1)O[C@H](c1cc(O)c(O)c(O)c1)[C@H](O)C2c1c(O)cc(O)c2c1O[C@H](c1cc(O)c(O)c(O)c1)[C@H](O)C2</smiles>

prodelphinidin B2 (13)<smiles>Oc1cc(O)c2c(c1)O[C@H](c1cc(O)c(O)c(O)c1)[C@H](O)[C@H]2c1c(O)cc(O)c2c1O[C@H](c1ccc(O)c(O)c1)[C@H](O)C2</smiles>

prodelphinid in B3 (14)<smiles>Oc1cc(O)c2c(c1)O[C@H](c1cc(O)c(O)c(O)c1)[C@H](O)[C@H]2c1c(O)cc(O)c2c1O[C@H](c1cc(O)c(O)c(O)c1)[C@H](O)C2</smiles>

prodelphinidin B4 (15)<smiles>Oc1cc(O)c2c(c1)O[C@H](c1cc(O)c(O)c(O)c1)[C@H](O)[C@H]2c1c(O)cc(O)c2c1O[C@H](c1cc(O)c(O)c(O)c1)[C@H](O)[C@H]2c1c(O)cc(O)c2c1O[C@H](c1ccc(O)c(O)c1)[C@H](O)C2</smiles>

prode lphinidin C2 (16)

Figure 2. The structures of prodelphinidins

\section{SYNTHESIS OF DIMERIC PROCYANIDINS}

\section{Synthesis of procyanidin B1 (1)-B4 (4)}

Early synthetic studies of procyanidin dimer can be dated back to 1965 reported by Creasy and Swain. ${ }^{14}$ They condensed 4-hydroxylated catechin with catechin using aqueous $0.4 \mathrm{M} \mathrm{HCl}$ to give corresponding dimer in good yield. However, the selectivity of regio- and stereochemistry of newly formed interflavan bond was not determined. They showed that 4-hydroxylated flavan was activated by acid and protonation at the C-4 hydroxy group generates cationic spieces. The synthesis of catechin dimers using non-protected catechins was ideal, however, the difficulty to purify the products because of the sensitivity by air and acids made synthesis problematic. Thus protected catechin derivatives were used to prepare dimeric products using Lewis acids. In 1991, Kawamoto and co-workers reported the condensation of per- $O$-benzylated catechin derivative $\mathbf{1 7}$ as a nucleophile using five times excess amount with electrophile 18 using $\mathrm{TiCl}_{4}$ as a Lewis acid to give the corresponding dimer 19 in high yield with good selectivity $(\alpha: \beta$ $=5: 1) .{ }^{15}$ It is notable that attack at the C-8 position was occurred exclusively (Scheme 1). 
<smiles>CC(O)Cc1cccc(OCc2ccccc2)c1</smiles>

17 (5.0 equiv.)

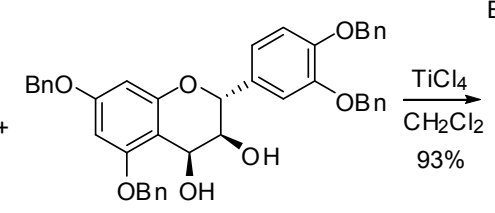

18

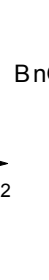<smiles>[B]CCOCCO</smiles><smiles></smiles>

19

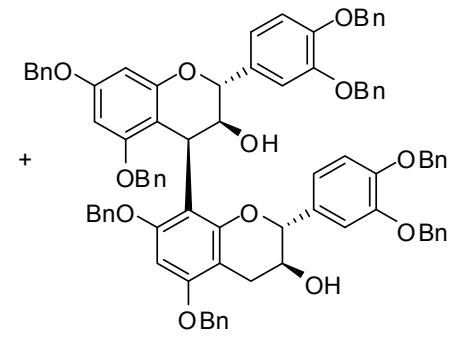

20

Scheme 1. Condensation of Bn-protected catechin nucleophile and electrophile

Since this report had been appeared, further synthetic studies have been reported. Ubukata and Nakajima reported excellent regio- and stereoselective condensation using 4-ethoxyethoxy group as an electrophile and TMSOTf as a Lewis acid and they synthesized procyanidin B3 (3) (Scheme 2). ${ }^{16}$

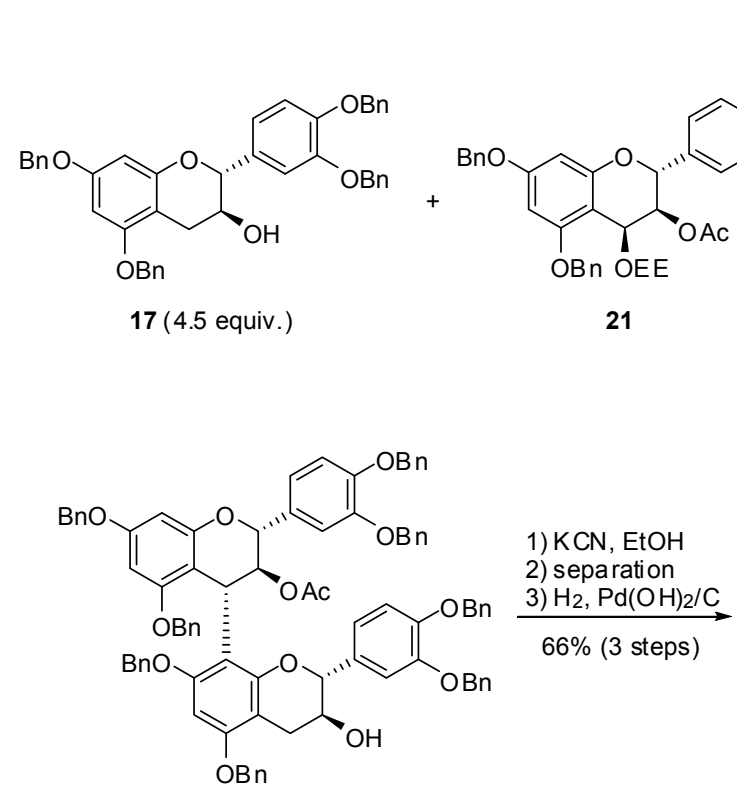

22

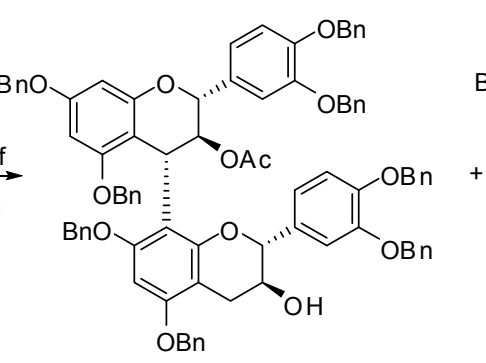

22<smiles>Oc1cc(O)c2c(c1)O[C@H](c1ccc(O)c(O)c1)[C@H](O)[C@H]2c1c(O)cc(O)c2c1O[C@H](c1ccc(O)c(O)c1)[C@H](O)C2</smiles>

procyanidin B3 (3)

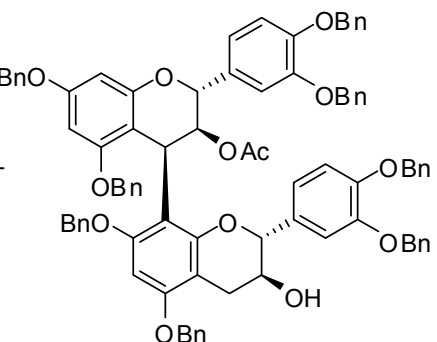

$(22: 23=49: 1)$

23

Scheme 2. Highly stereoselective condensation of Bn-protected catechin nucleophile and electrophile and its application to the synthesis of procyanidin B3 (3)

The neighboring group participation of C-3 acetoxy group seemed to be effective to form 3,4-anti selective interflavan bond (Figure 3). ${ }^{16,17}$ 


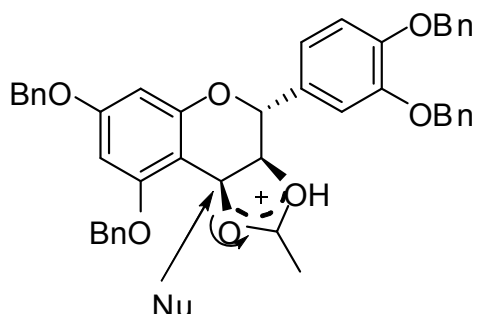

Figure 3. Neighboring group participation of 3-acetoxy electrophile in the condensation

They also accomplished stereoselective condensation of catechin and/or epicatechin nucleophile and electrophile and total synthesis of procyanidins B1 (1), B2 (2), and B4 (4), respectively (Scheme 3). ${ }^{18}$

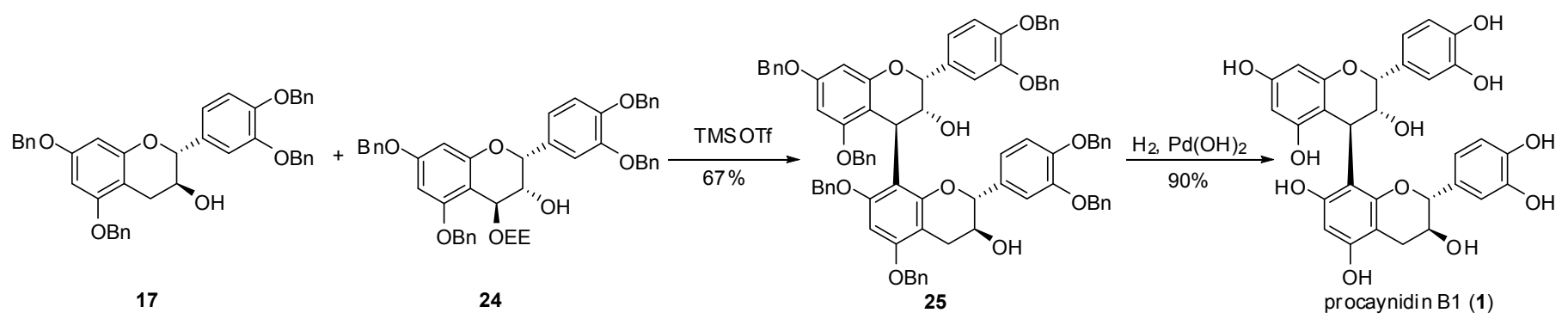

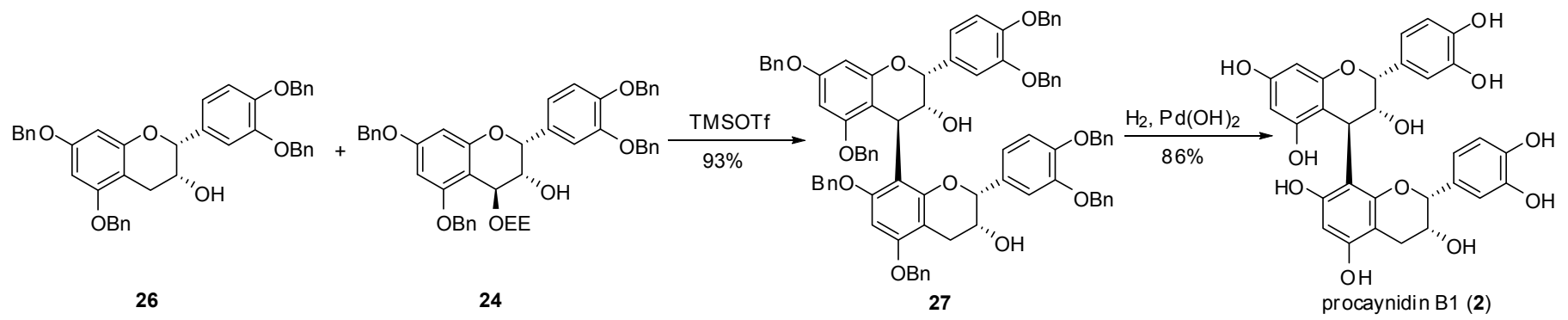

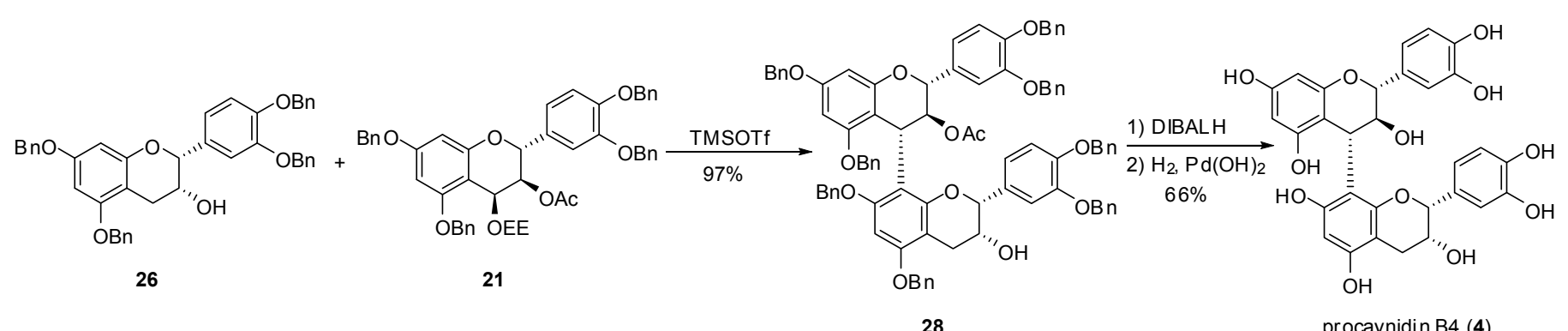

Scheme 3. Catechin and/or epicatechin nucleophile and electrophile and total synthesis of procyanidins B1 (1), B2 (2), and B4 (4)

The same group also reported the synthesis of procyanidin B2 and B3 gallates using same strategy (Scheme 4). ${ }^{8,19}$ 

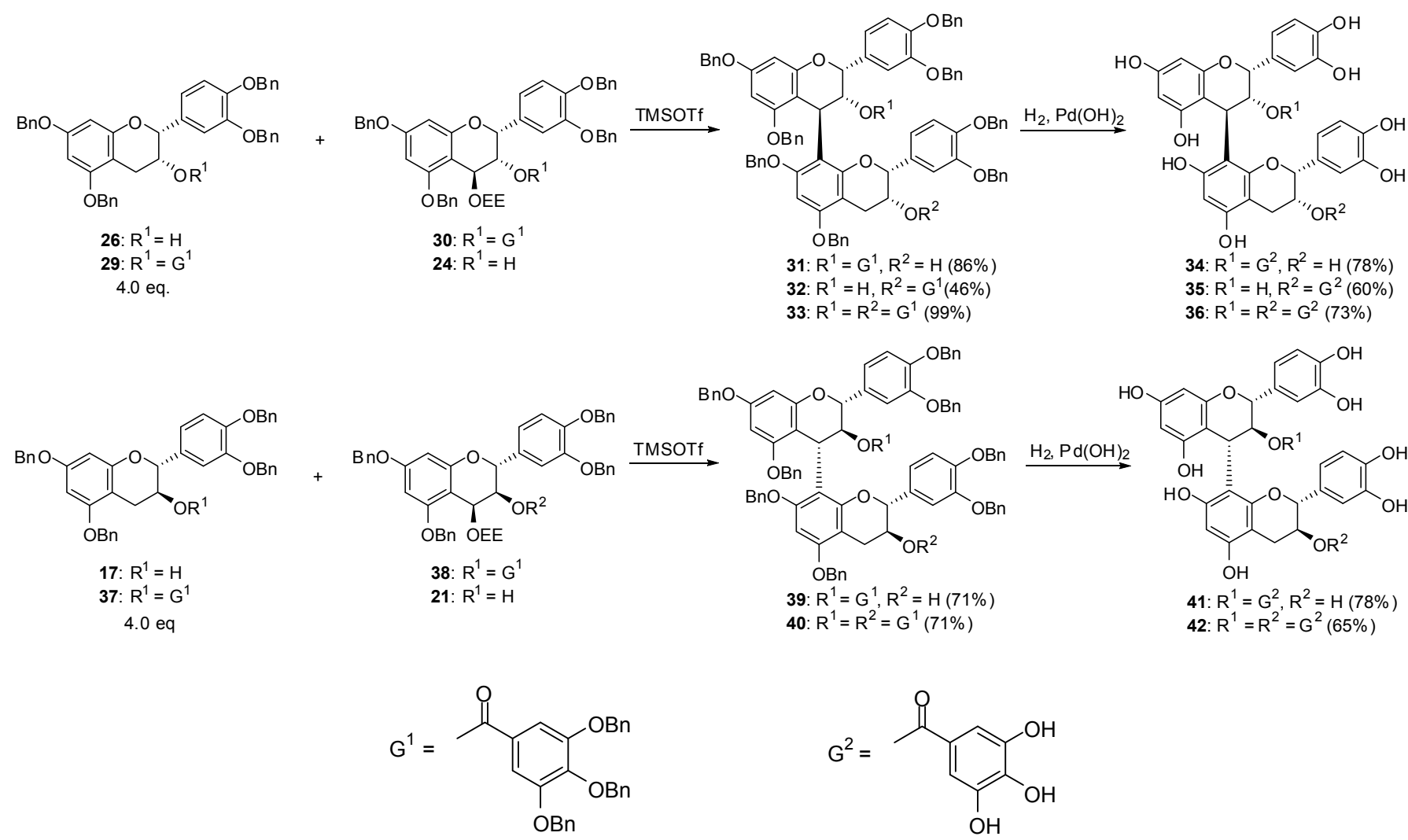

Scheme 4. Synthesis of procyanidin B2 and B3 gallates using TMSOTf as a Lewis acid

Using protected catechin delivatives blocks provided promising dimeric products with excellent regiostereoselectivity. However, this reaction requires a large excess amount of the nucleophile (4-5 equiv.) in order to suppress forming the higher oligomers. In view of purification after condensation, the remained nucleophile needs to be removed. To overcome this problem, Makabe and co-workers investigated Lewis acid mediated equimolar condensation. ${ }^{20,21}$ They chose tetrabenzylated catechin $\mathbf{1 7}$, as a nucleophilic unit, prepared by the Kawamoto's procedure ${ }^{15}$ and electrophile unit $\mathbf{4 3}$ prepared by the Saito's method. ${ }^{16}$ Equimolar condensation of $\mathbf{1 7}$ with $\mathbf{4 3}$ at room temperature was examined using various Lewis acids including rare earth metal at room temperature (Table 1).

Table 1. Lewis acids mediated equimolar coupling reaction between catechin nucleophile $\mathbf{1 7}$ and its electrophile 43

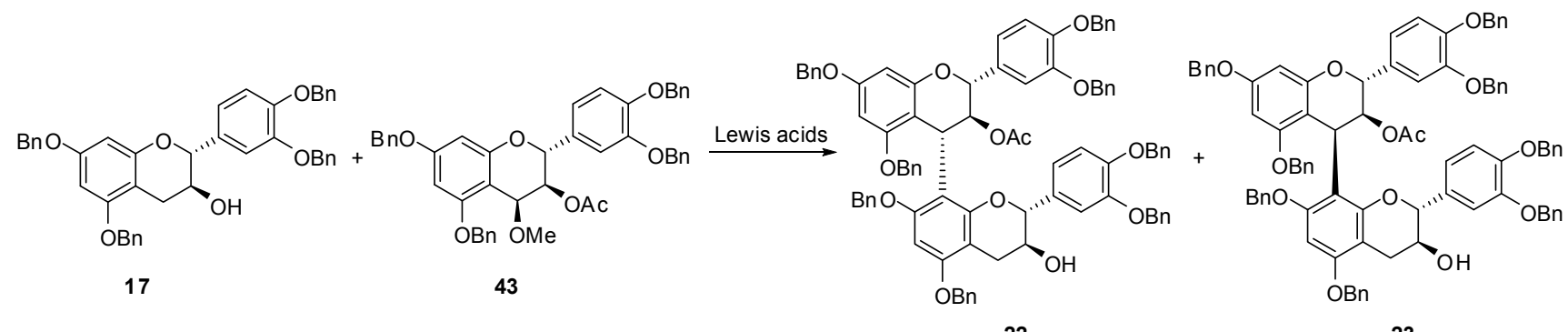




\begin{tabular}{|c|c|c|c|}
\hline Lewis acids $^{a}$ & Time $(\mathrm{h})$ & Yield (\%) & Selectivity $(22: 23)^{b}$ \\
\hline $\mathrm{TiCl}_{4}$ & 0.5 & 36 & $75: 25$ \\
\hline $\mathrm{BF}_{3} \cdot \mathrm{Et}_{2} \mathrm{O}$ & 3 & ND & - \\
\hline $\mathrm{B}\left(\mathrm{C}_{6} \mathrm{H}_{5}\right)_{3}$ & 2 & 38 & $89: 11$ \\
\hline $\mathrm{AgBF}_{4}$ & 7.5 & 50 & $98: 2$ \\
\hline $\mathrm{Cu}(\mathrm{OTf})_{3}$ & 0.5 & 43 & $91: 9$ \\
\hline $\ln (\mathrm{OTf})_{3}$ & 0.5 & 45 & $91: 9$ \\
\hline $\mathrm{Sc}(\mathrm{OTf})_{3}$ & 0.5 & 50 & $67: 33$ \\
\hline $\mathrm{La}(\mathrm{OTf})_{3}$ & 72 & 34 & $98: 2$ \\
\hline $\mathrm{Gd}(\mathrm{OTf})_{3}$ & 72 & NR & - \\
\hline $\mathrm{Lu}(\mathrm{OTf})_{3}$ & 72 & $N R$ & - \\
\hline $\mathrm{Yb}(\mathrm{OTf})_{3}$ & 2 & 64 & $98: 2$ \\
\hline $10 \mathrm{~mol} \%$ of $\mathrm{Yb}(\mathrm{OTf})_{3}$ & 12 & 42 & $91: 9$ \\
\hline
\end{tabular}

$\mathrm{a}_{1}$ equivalent of Lewis acid was used otherwise noted.

${ }^{\mathrm{b}}$ The selectivity was determine d by ${ }^{1} \mathrm{H}$ NMR analysis of $\mathrm{C}-3$ position of diacetate derivative of 22 (5.80 and $5.83 \mathrm{ppm}$ ) and 23 (5.53 and $5.58 \mathrm{ppm}$ ) according to the reported procedure. ${ }^{16}$

Using $\mathrm{TiCl}_{4}$ and $\mathrm{BF}_{3} \cdot \mathrm{Et}_{2} \mathrm{O}$ gave sluggish results. The next attempt was examined using late transition metals as Lewis acids. Among them, $\mathrm{AgBF}_{4}$ gave a good selectivity with moderate chemical yield. They further paid attention to rare metal Lewis acids such as Sc and La. While Sc gave poor stereoselectivity, La afforded high selectivity although the chemical yield was only $34 \%$. Finally, replacing $\mathrm{La}$ to $\mathrm{Yb}$ furnished condensed product in 64\% yield with excellent selectivity. Interestingly, $\mathrm{Gd}(\mathrm{OTf})_{3}$ and $\mathrm{Lu}(\mathrm{OTf})_{3}$ did not give any condensed product. Next, they expanded the condensation of the combination of catechin nucleophile 17 and epicatechin nucleophile 26 with catechin electrophile 43 and/or epicatechin electrophile 44 using $\mathrm{Yb}(\mathrm{OTf})_{3}$ as a Lewis acid. In each case, the reaction worked well. In view of the stereoselectivty, however, the epicatechin electrophile $\mathbf{4 4}$ gave a little bit poor results compared to catechin electrophile $\mathbf{4 3}$. Condensed compounds $45,46,22$, and 47 were subjected to the hydrolysis of the acetate with $\mathrm{K}_{2} \mathrm{CO}_{3}$ in $\mathrm{MeOH}$ followed by debenzylidation by $\mathrm{Pd}(\mathrm{OH})_{2}$ to give procyanidin B1 (1)-B4 (4), respectively (Scheme 5). 


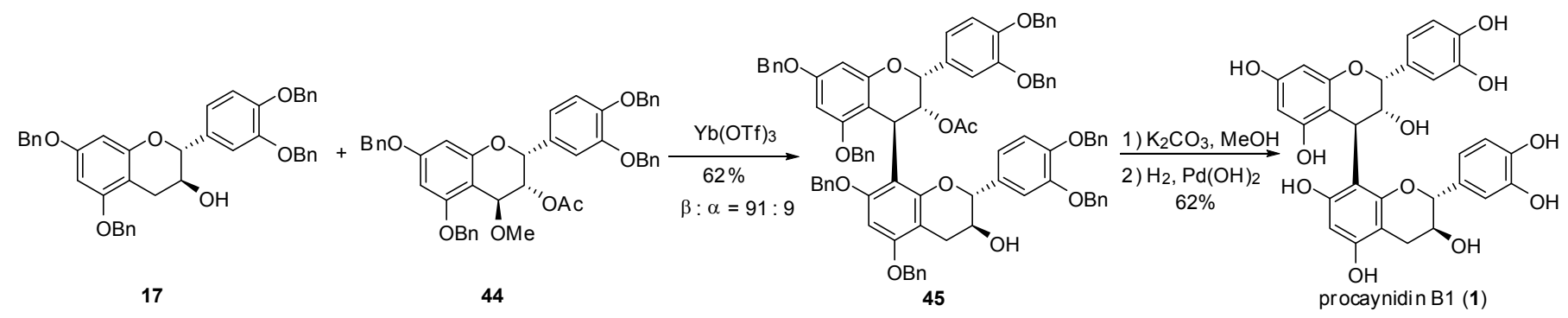

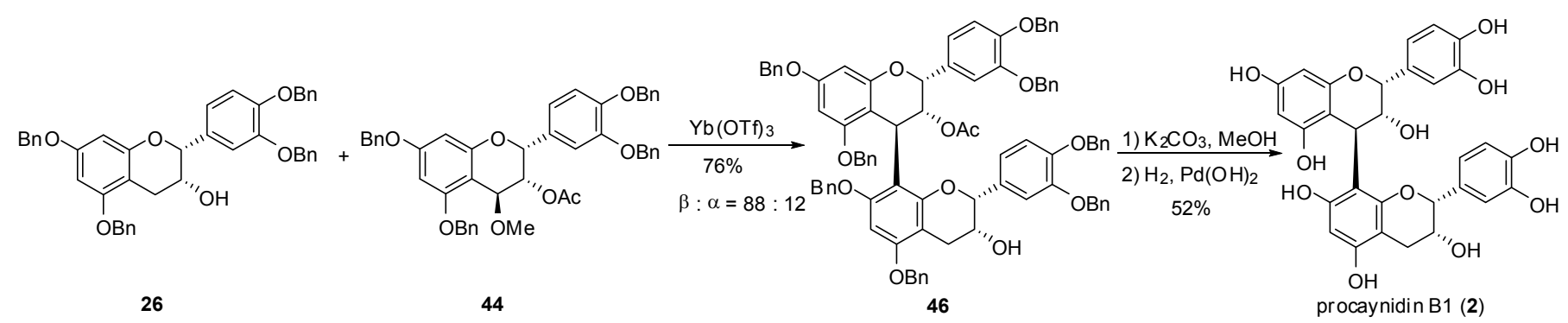

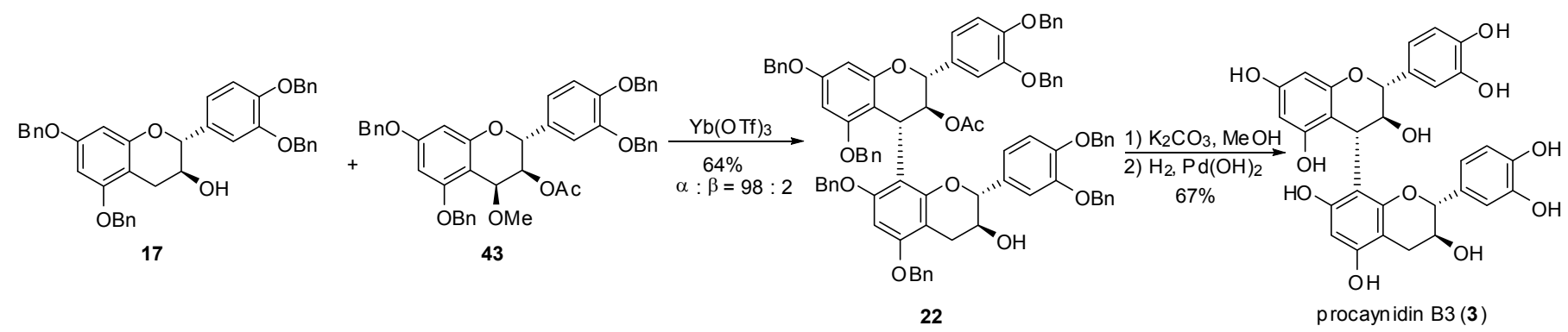

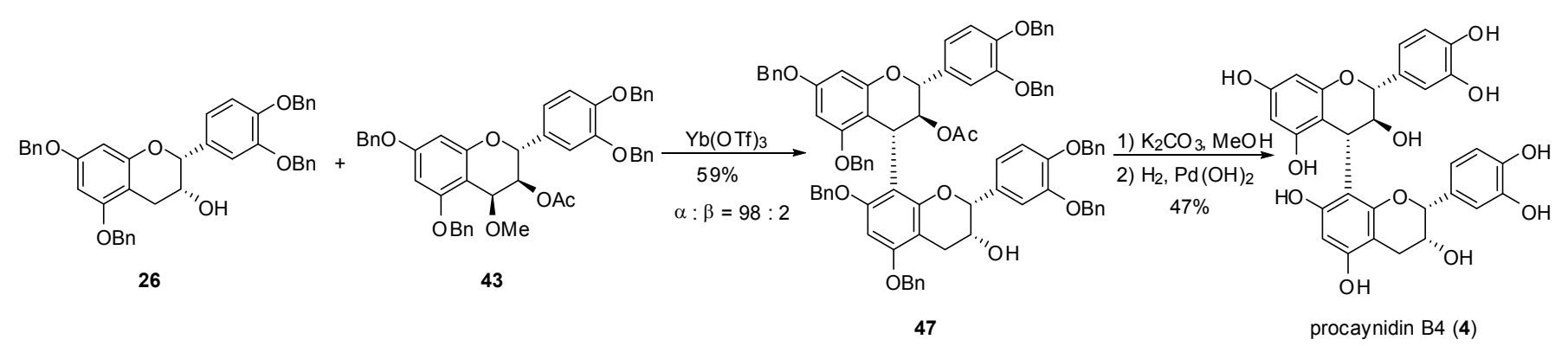

Scheme 5. Synthesis of procyanidin B1-B4 (1-4) using equimolar condensation mediated by $\mathrm{Yb}(\mathrm{OTf})_{3}$

The author's group also reported procyanidin B2 and B3 gallates and their anticancer activity using equimolar condensation (Scheme 6). ${ }^{22}$ 

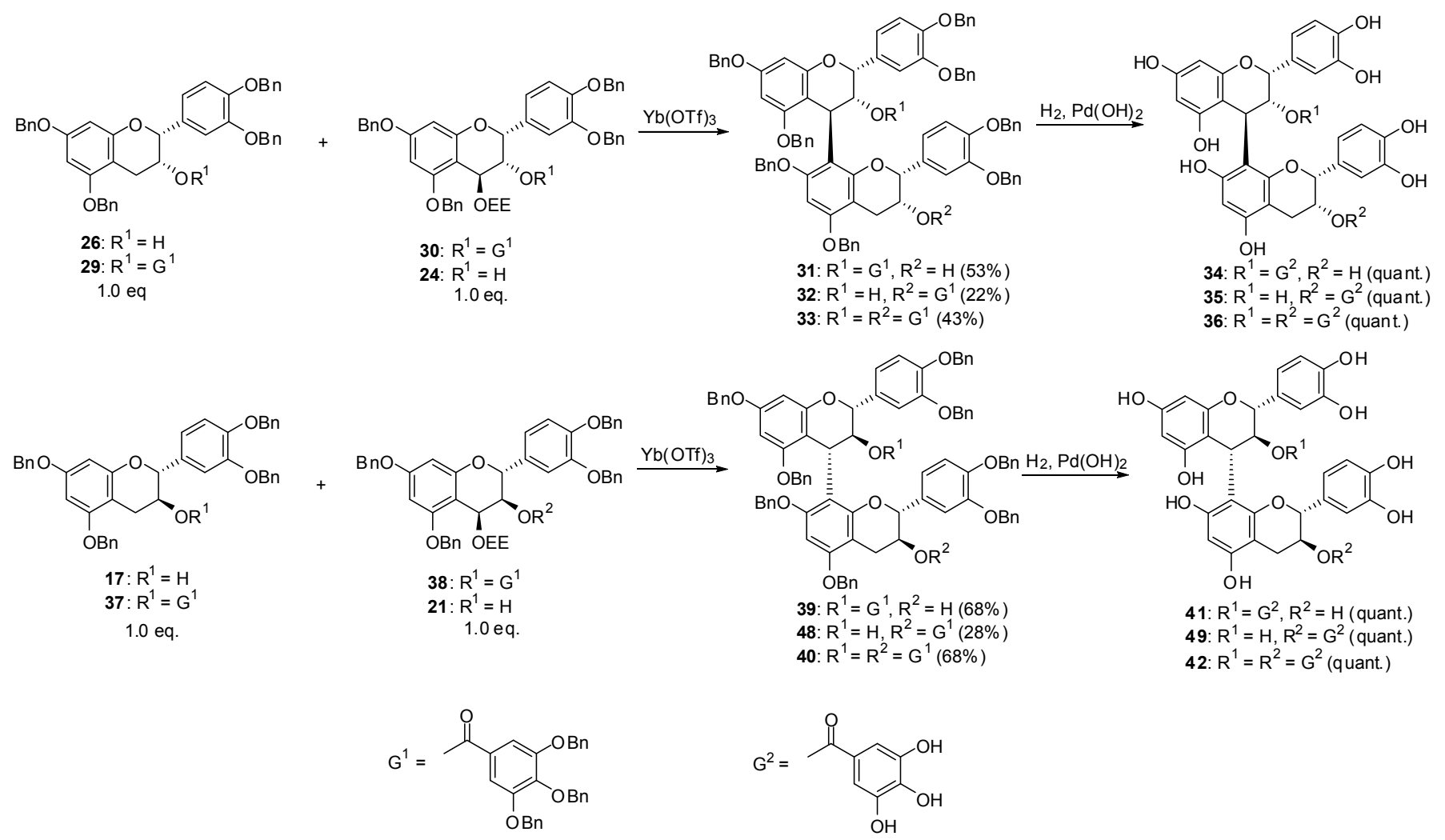

Scheme 6. Synthesis of procyanidin B2 and B3 gallates using equimolar condensation mediated by $\mathrm{Yb}(\mathrm{OTf})_{3}$

\section{Synthesis of procyanidin B6 (5)}

Quite recently, Ohmori and Suzuki et al. accomplished first total synthesis of procyanidin B6 (5) which has a rare 4,6-inter-flavan bond. They succeeded regioselective linkage by the halogen-capping strategy followed by removal of the benzyl groups and halogen-caps by one-pot hydrogenolysis (Scheme 7). ${ }^{23}$

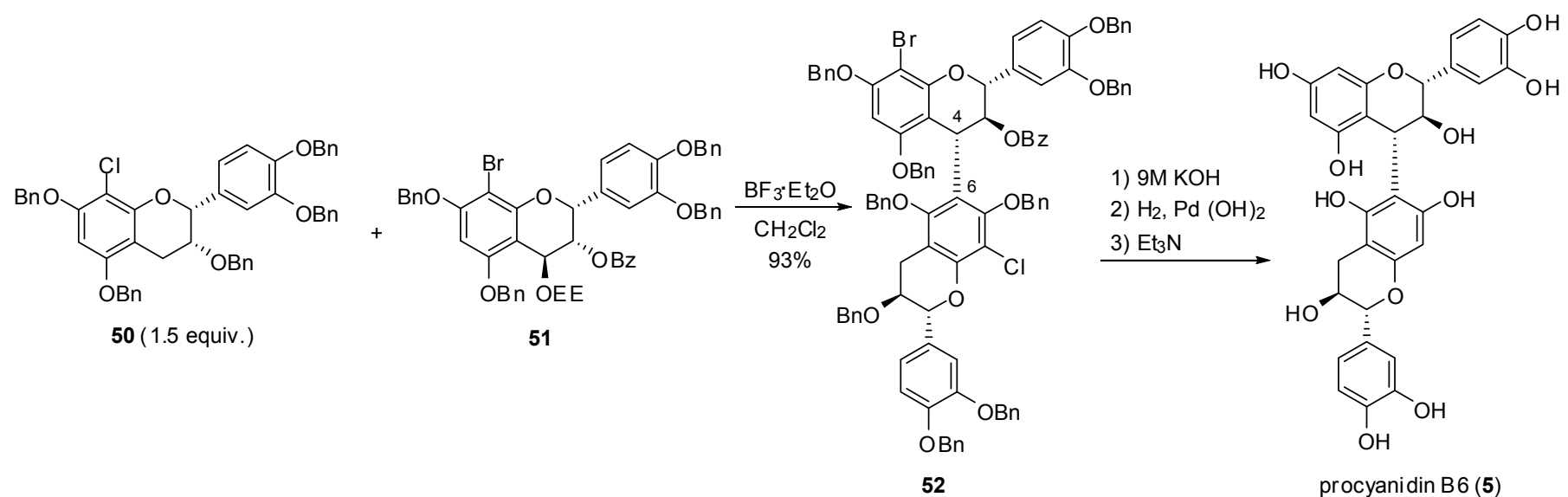

Scheme 7. Synthesis of procyanidin B6 (5) 


\section{SYNTHESIS OF TRIMERIC PROCYANIDINS}

\section{Synthesis of procyanidin C1 (6) and C2 (7)}

Saito and Nakajima et al. reported TMSOTf mediated condensation of monomeric catechin electrophile 21 with nucleophilic dimer 19 for synthesis of procyanidin C2 (7). However, this reaction needed a large excess amount of nucleophilic dimer 19 (4.0-4.5 equiv.) to avoid further oligomer formation (Scheme $8) .^{24,25}$
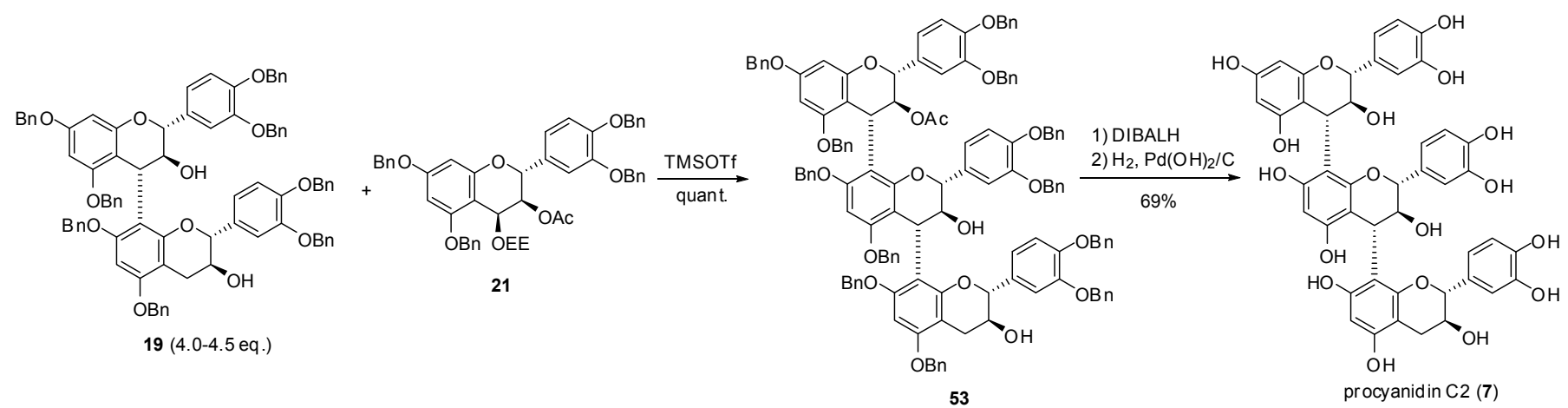

Scheme 8. Synthesis of procyanidin C2 (7) using excess amount of dimeric nucleophile

To overcome this problem, Ohmori and Suzuki et al. developed the orthogonal approach for synthesis of catechin trimer. ${ }^{26}$ The acetoxy group served as an orthogonal leaving group that was activated hard Lewis acid $\left(\mathrm{BF}_{3} \cdot \mathrm{OEt}_{2}\right)$. Another important chemical feature of this reaction is the Br-capping of the C-8 position to suppress the self-condensation. Thus the amount of nucleophile could be reduced to 1.2 equivalent (Scheme 9).

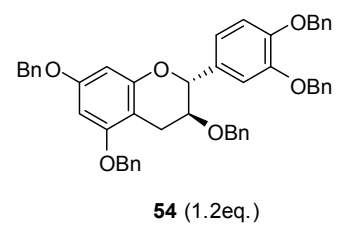

54 (1.2eq.)

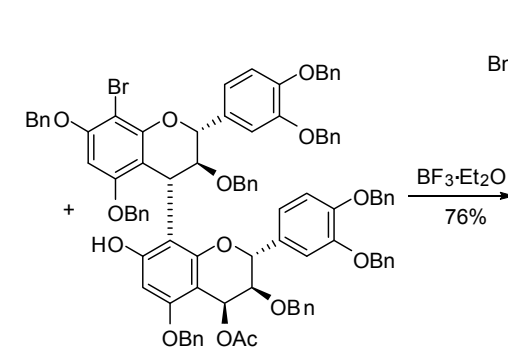

55

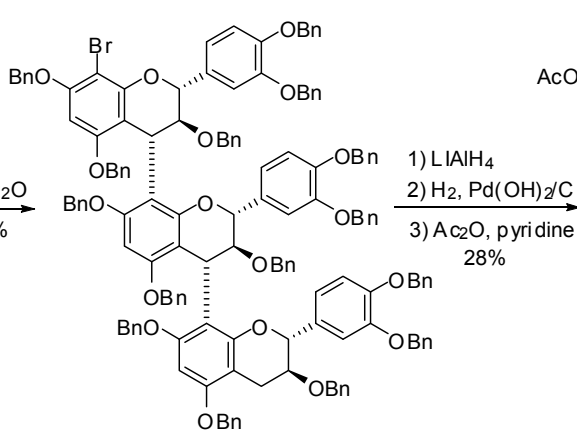

56

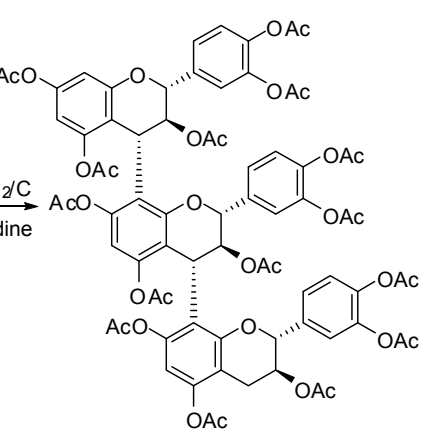

peracetate of procyanidin $\mathrm{C} 2(\mathbf{4 1})$

Scheme 9. Orthogonal approach for the synthesis of peracetate of procyanidin C2 (41)

The same group also synthesized epiafzelechin-epigallogatechin-catechin (EZ-EG-CA) (61) using similar strategy (Scheme 10). ${ }^{27}$ 


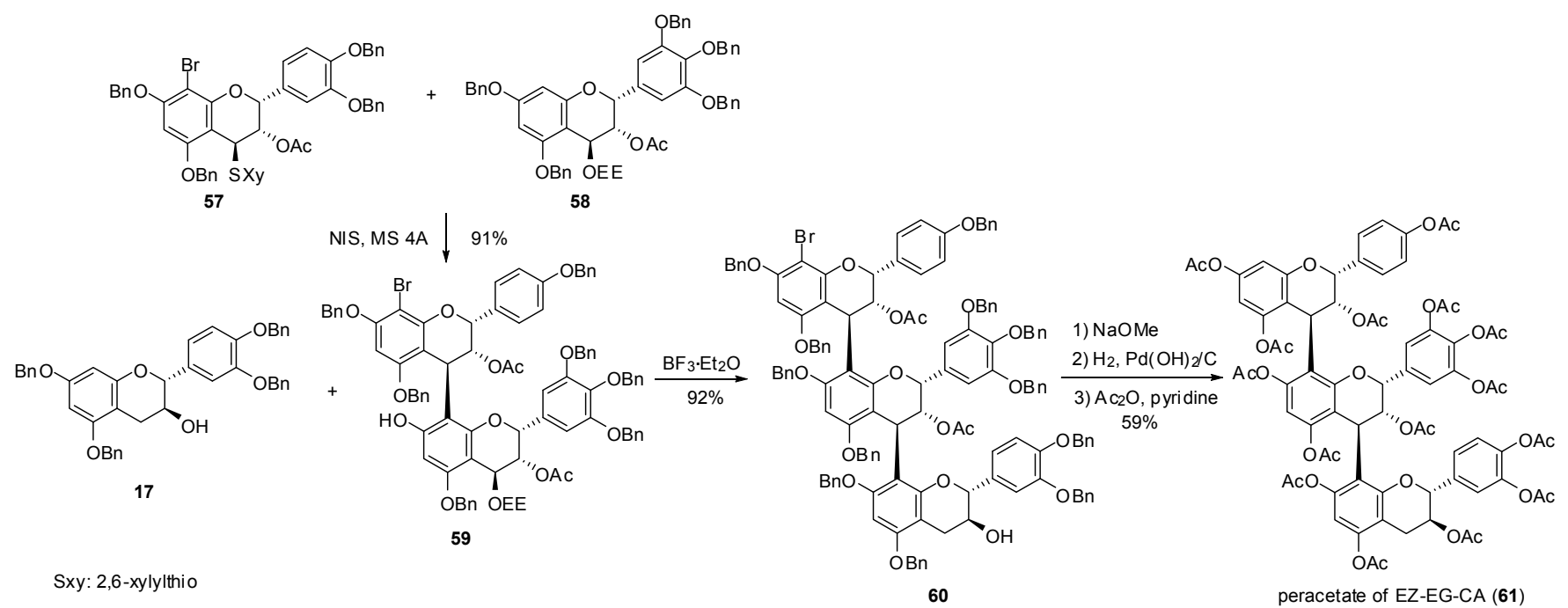

Scheme 10. Synthesis of EZ-EG-CA (61) using orthogonal approach

Makabe and co-workers also reported the synthesis of catechin and epicatechin trimer (procyanidin $\mathrm{C} 1$ (6) and C2 (7)) using equimolar condensation. ${ }^{28,29}$ Equimolar condensation of 19 with 43 was examined using transition metal Lewis acids and $\mathrm{Yb}(\mathrm{OTf})_{3}$ in $\mathrm{CH}_{2} \mathrm{Cl}_{2}$. They paid attention to silver Lewis acid because condensation could be performed under neutral conditions. According to Ferreira and co-workers' report, using $\mathrm{AgBF}_{4}$ as the thiophilic Lewis acid offered advantages to control the level of oligomeration in the procyanidin B1-B4 and C2 synthesis. ${ }^{30}$ As shown in Table 1, AgBF 4 and AgOTf gave 53 in excellent yield, respectively. However, $\mathrm{Yb}(\mathrm{OTf})_{3}$ afforded low yield. Due to the steric hindrance of $\mathrm{Yb}(\mathrm{OTf})_{3}$, it seemed to be difficult for dimeric nucleophile 19 to attack C-4 position of electrophile $\mathbf{4 3}$ (Table 2).

Table 2. Equimolar coupling reaction of $\mathbf{1 9}$ with $\mathbf{4 3}$ by Lewis acids ${ }^{\mathrm{a}}$
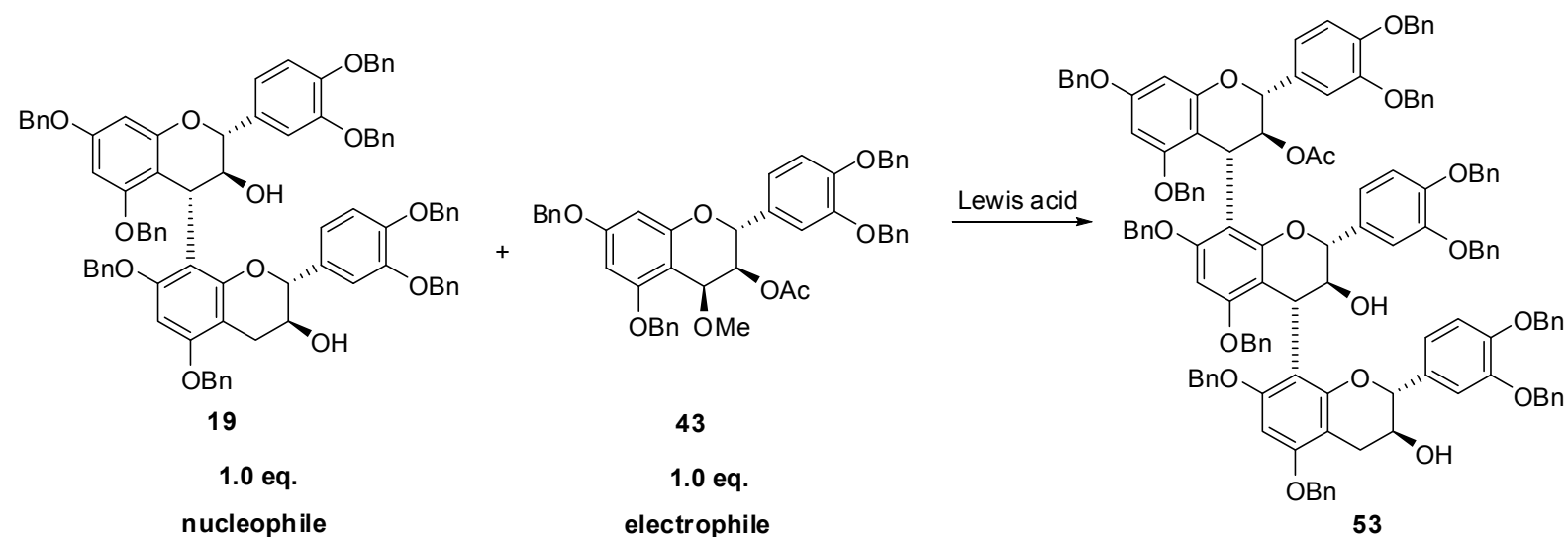


\begin{tabular}{lcc}
\hline Lewis acids $^{\mathrm{b}}$ & Time $(\mathrm{h})$ & Yield $(\%)$ \\
\hline $\mathrm{Yb}(\mathrm{OTf})_{3}$ & 12 & 13 \\
$\mathrm{Cu}(\mathrm{OTf})_{2}$ & 3 & 23 \\
$\mathrm{AgBF}_{4}$ & 3 & 85 \\
$\mathrm{AgOTf}$ & 3 & 86 \\
\hline
\end{tabular}

${ }^{a}$ The reaction was carried out at room temperature in $\mathrm{CH}_{2} \mathrm{Cl}_{2}$.

b1.0 equivalent of Lewis acid was used.

Condensed product 53 was successfully converted into procyanidin $\mathrm{C} 2(\mathbf{7})$ and its peracetate (63). The ${ }^{1} \mathrm{H}$ NMR spectral data of peracetate $\mathbf{6 3}$ was in good agreement with that of the reported value. ${ }^{31}$ (Scheme 11).

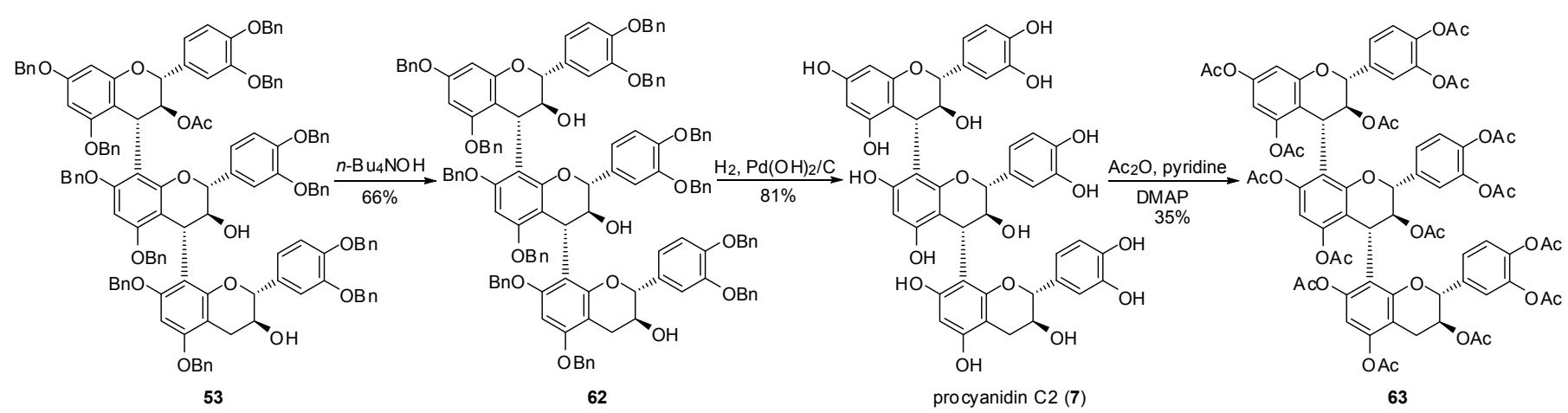

Scheme 11. Synthesis of procyanidin C2 (7) and its peracetate 63

As to the synthesis of procyanidin $\mathrm{C} 1$ (6), equimolar condensation of 27 with 44 was examined using transition metal Lewis acids and $\mathrm{Yb}(\mathrm{OTf})_{3}$ in $\mathrm{CH}_{2} \mathrm{Cl}_{2}$. Condensation using $\mathrm{AgBF}_{4}$ and $\mathrm{AgOTf}$ resulted condensed product $\mathbf{6 6}$ in low yield. Next we examined equimolar condensation of 27 with various 4-alkoxy-epicatechin derivatives 44, 64, 65, and 24 using $\mathrm{Yb}(\mathrm{OTf})_{3}$. As shown in Table 3, 4-(2"-ethoxyethoxy) derivative 24 afforded condensed product 66 in 57\% yield. Other 4-alkoxy derivatives gave $\mathbf{6 6}$ in low yield and both of the nucleophile and electrophile remained. We found that 4-(2"-ethoxyethoxy) group was suitable for $\mathrm{Yb}(\mathrm{OTf})_{3}$ mediated activation at C-4 position of electrophile. 
Table 3. Equimolar condensation of 4-alkoxy-epicatechin derivatives 44, 64, 65 and 24 with dimeric epicatechin nuceophile 27 by $\mathrm{Yb}(\mathrm{OTf})_{3}$

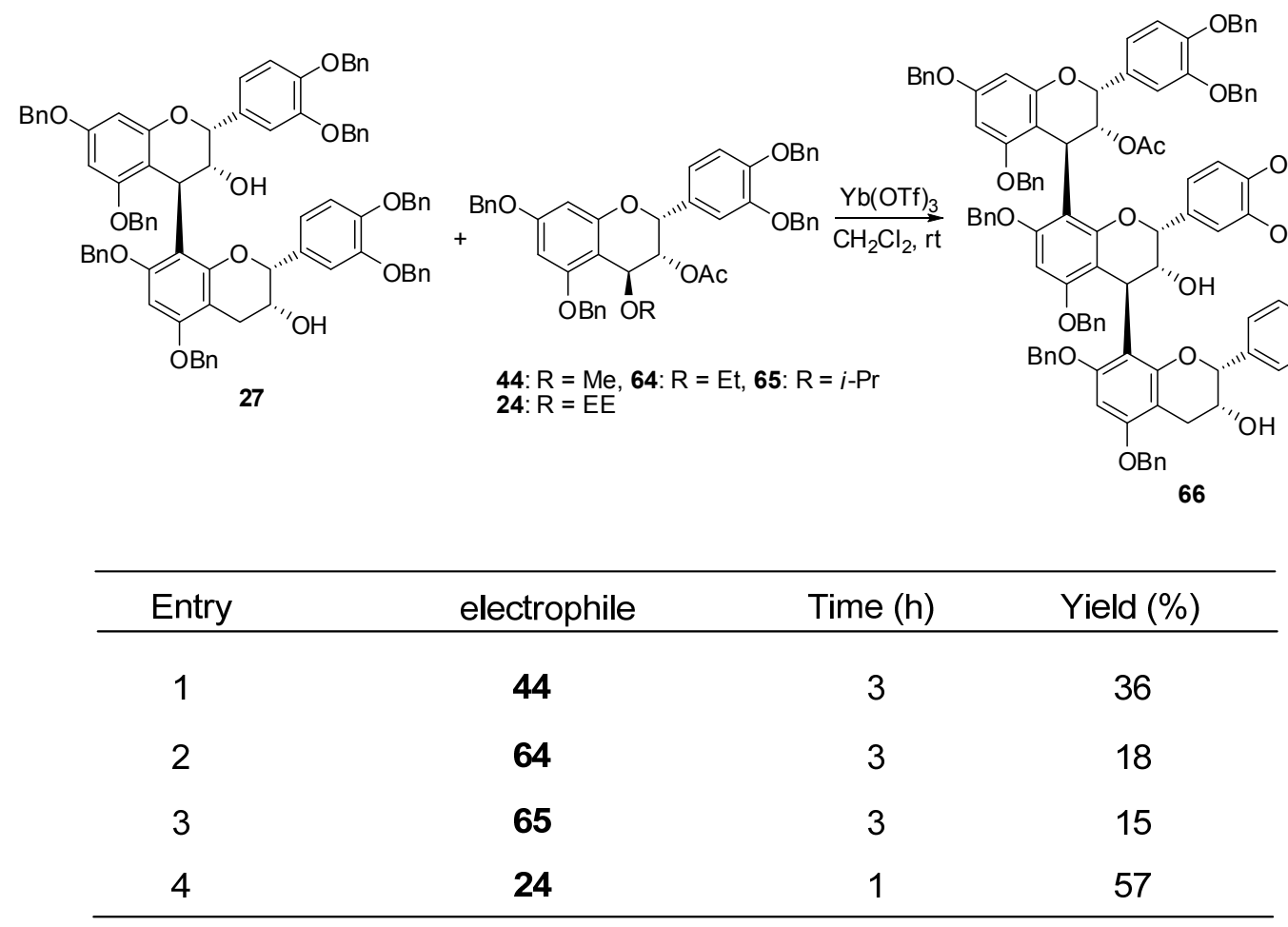

The condensed product 66 was transformed into triol 67 using $n-\mathrm{Bu}_{4} \mathrm{NOH}$. Finally deprotection of the benzyl group of 67 subsequent lyophilization afforded procyanidin $\mathrm{C} 1(\mathbf{6})$ in good yield. ${ }^{29}$ The ${ }^{1} \mathrm{H}$ NMR spectral datum of peracetate $\mathbf{6 8}$ was in good agreement with that of the reported value (Scheme 12). ${ }^{31}$

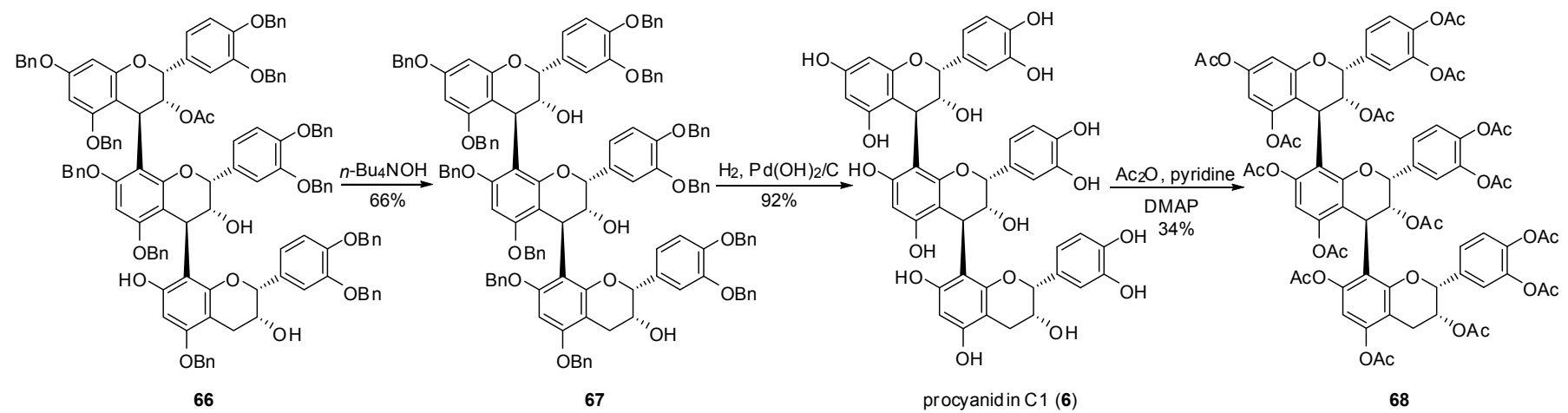

Scheme 12. Synthesis of procyanidin C1 (6) and its peracetate 68

\section{SYNTHESIS OF HIGHER OLIGOMERS}

First challenge of the synthesis procyanidin oligomer was reported by Kozikowski and co-workers. ${ }^{32}$ Thio ether 69 and epicatechin dimer derivative 70 were treated with excess amount of $\mathrm{AgBF}_{4}$ gave multiple 
oligomerized products. Each compound was separated by HPLC and isolated products were evaluated antitumor activity (Scheme 13).<smiles>CC(C)(C)c1cc(OCc2ccccc2)c(OCc2ccccc2)c2c1O[C@H](c1ccc(OCc3ccccc3)c(OCc3ccccc3)c1)[C@@H](O)C2Sc1nc2ccccc2s1</smiles>

69

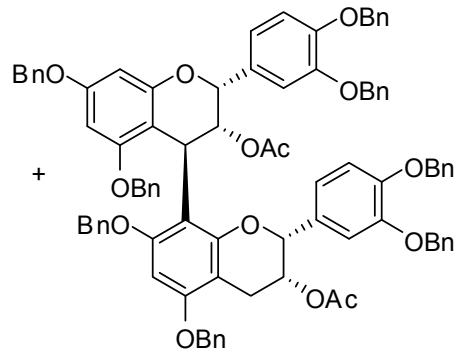

70 (2.5 eq.)
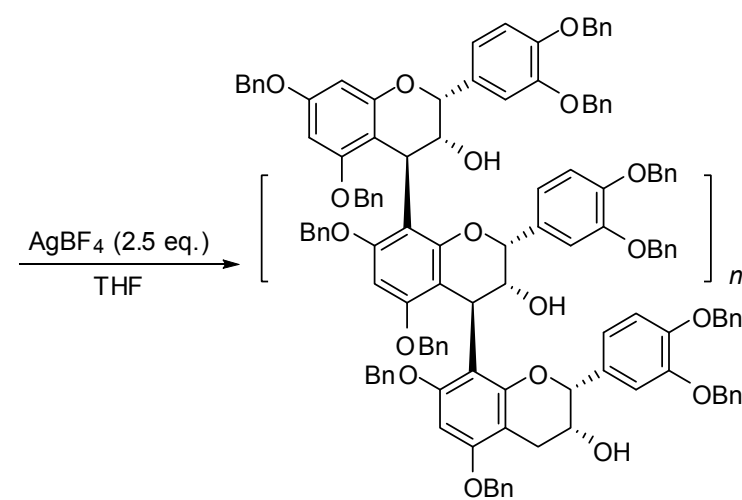

$n=1: 58 \%$

$n=2: 31 \%$

$\mathrm{n}=3: 8 \%$

$n=4: 2 \%$

$n=5: 0.2 \%$ $n=6:$ trace

Scheme 13. Multiple formation of epicatechin oligomers

Saito and Nakajima et al. reported TMSOTf mediated condensation of monomeric epicatechin electrophile 24 with nucleophilic trimer 67 to afford 71. This reaction also needed a large excess amount of nucleophilic trimer 67 (4.0 equiv.) to avoid further oligomer formation. The condensed product 71 was successfully converted to cinnamtannin A2 (8) (Scheme 14). ${ }^{33}$

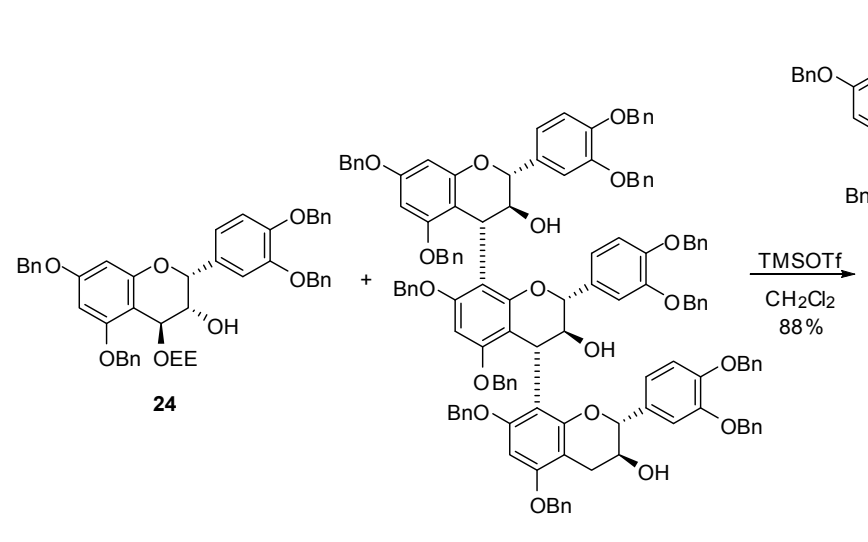

67 (4.0 eq) $\sqrt{20}$
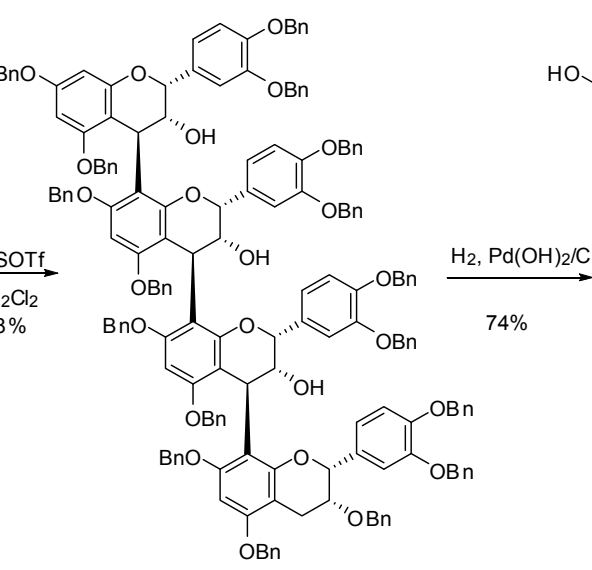

71

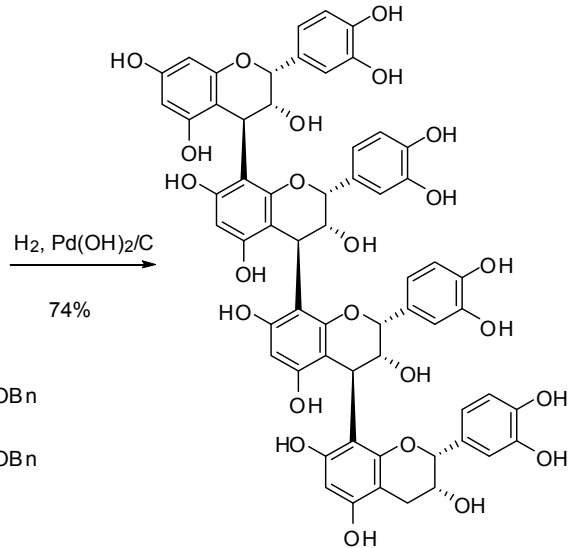

cinnamtannin A2 (8)

Scheme 14. Synthesis of cinnamtannin A2 (8)

Several studies demonstrated non-oligomeric selective self-polymerization. Kondo and co-workers performed non-selective oligomerization of 3,4-diacetoxy-flavan 72 mediated by $\mathrm{B}\left(\mathrm{C}_{6} \mathrm{~F}_{5}\right)_{3}$. They obtained 
the mixture of higher oligomers up to pentadecamer. The stereochemistry of newly formed interflavan bonds was not determined (Scheme 15). ${ }^{34}$<smiles>CC(=O)OCc1ccccc1OCCc1ccccc1</smiles>

72

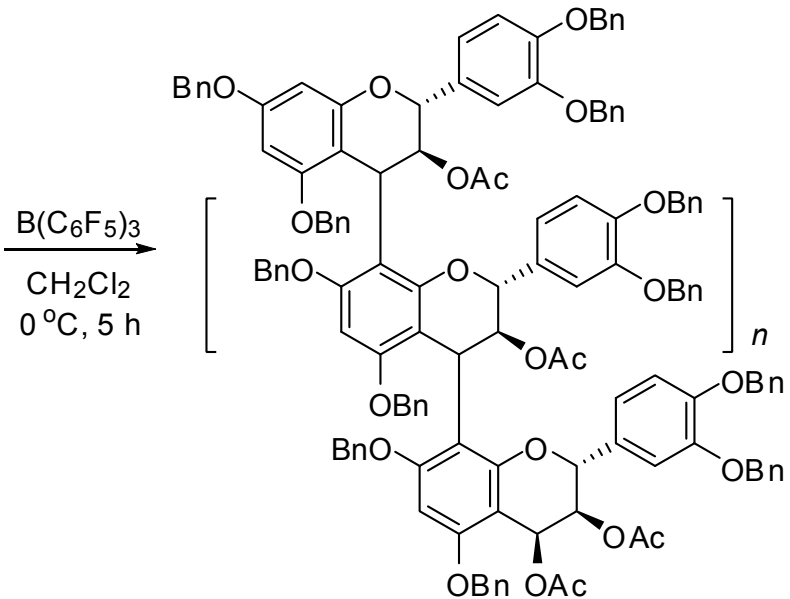

up to $\mathrm{n}=15$

Scheme 15. Oligomerization of 3,4-diacetoxy-flavan mediated by $\mathrm{B}\left(\mathrm{C}_{6} \mathrm{~F}_{5}\right)_{3}$

Recently, an elegant selective synthesis of higher oligomers up to the tetracosamer was accomplished using orthogonal strategy by Ohmori and Suzuki et al. ${ }^{35}$ The important matter for the orthogonal activation was the choice of leaving groups at C-4 position. They selected 4-ethoxyethoxy group for hard activation and the 2,6-xylylthio (SXy) group for soft activation. The bromo-capped electrophiles could be subjected to equimolar condensation with large nucleophiles (up to dodecamer). First, they prepared catechin hexamers $\mathbf{7 5}$ and $\mathbf{7 7}$ in a stereoselective manner. To confirm a stereochemistry of newly formed inter-flavan bond, they synthesized hexamer 75 independently by $\{2+4\}$ coupling using structurally defined dimer $\mathbf{7 8}$ and tetramer $\mathbf{7 9}$ (Scheme 16). 


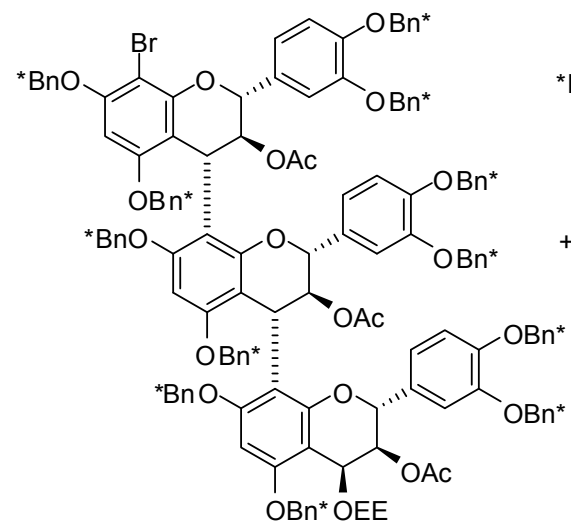

73

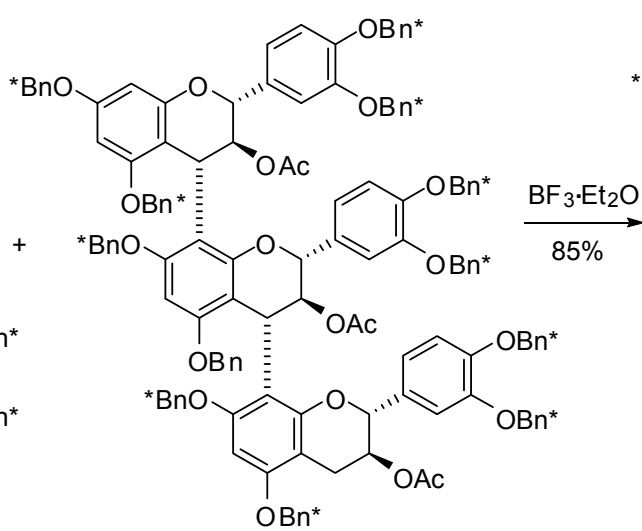

74 (1.2 eq.)

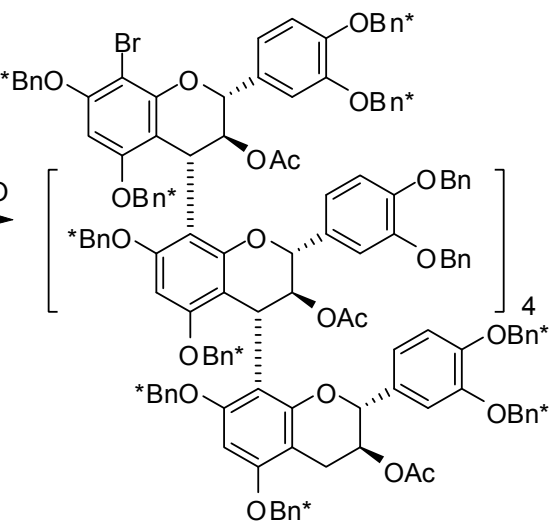

75

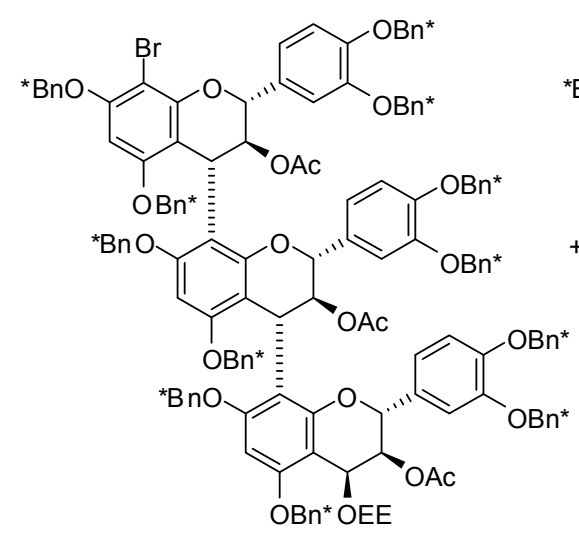

73

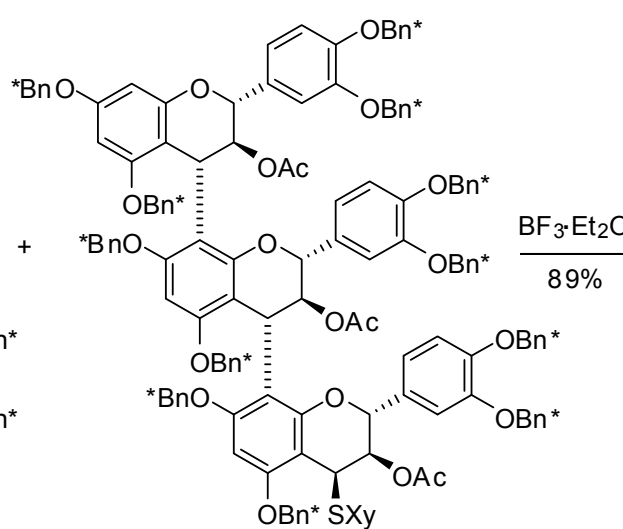

76 (1.2 eq.)

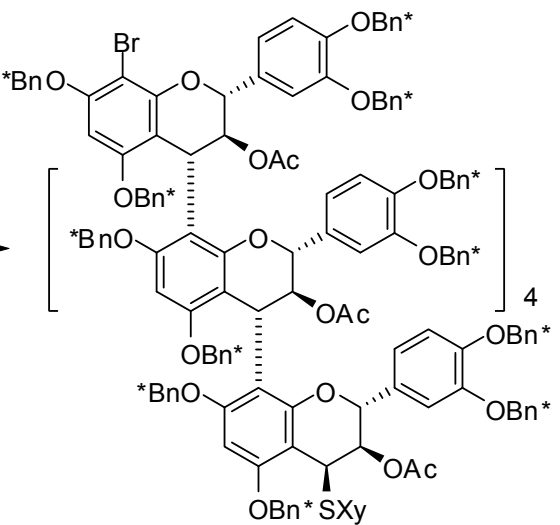

77

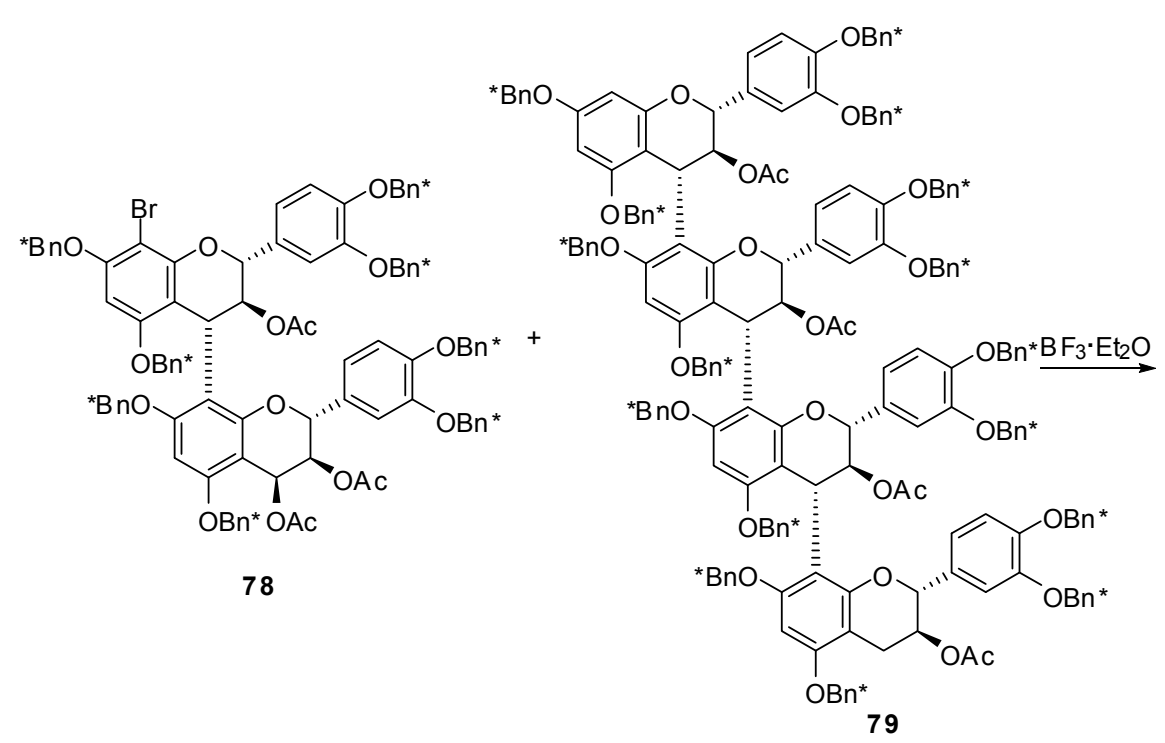

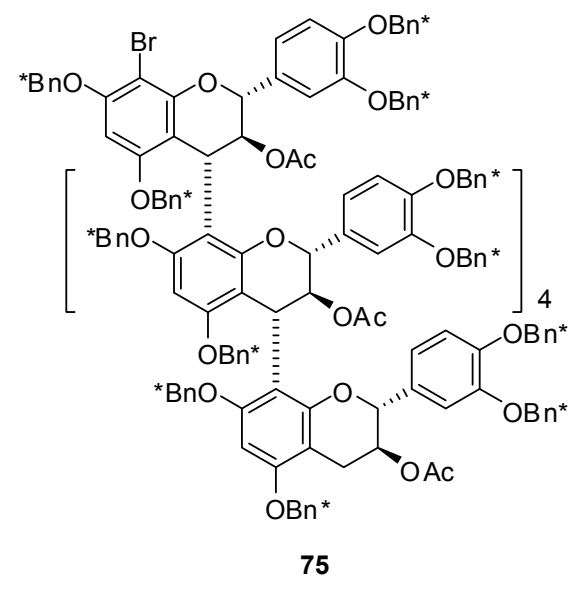

$\mathrm{Bn}^{*}:\left[\mathrm{D}_{7}\right] \mathrm{benzyl}, \mathrm{SXy}:$ 2,6-xylylthio

Scheme 16. Synthesis of catechin hexamers by the $\{3+3\}$ coupling using orthogonal strategy

Next, they prepared two dodecamers 82 and 84 using $\{6+6\}$ coupling. The stereochemistry of newly formed interflavan bonds was not determined (Scheme 17). 


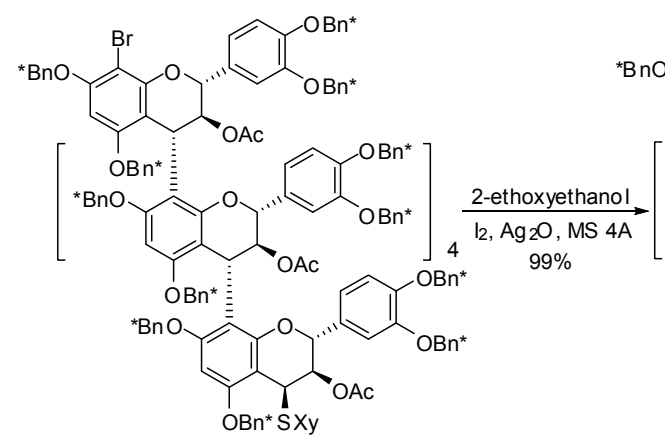

77

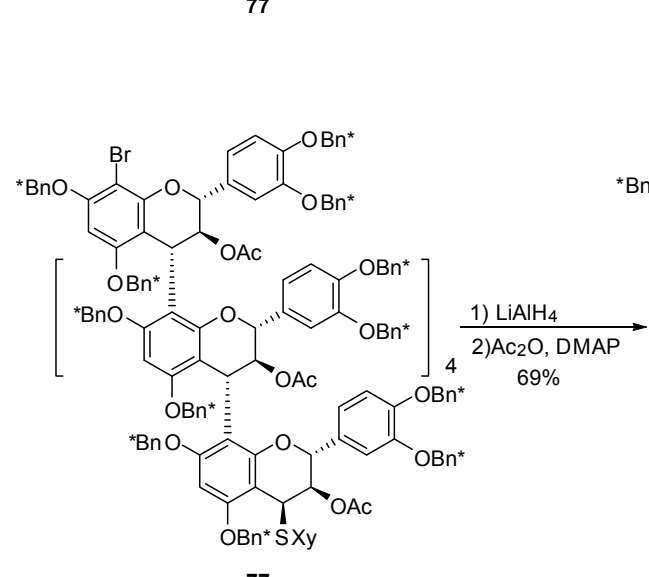

77

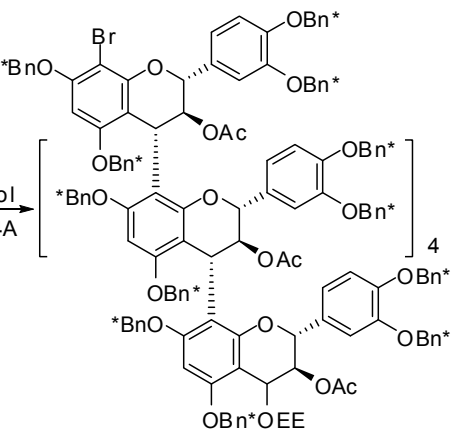

80

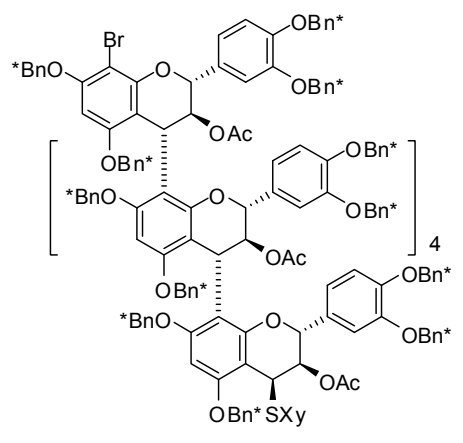

77

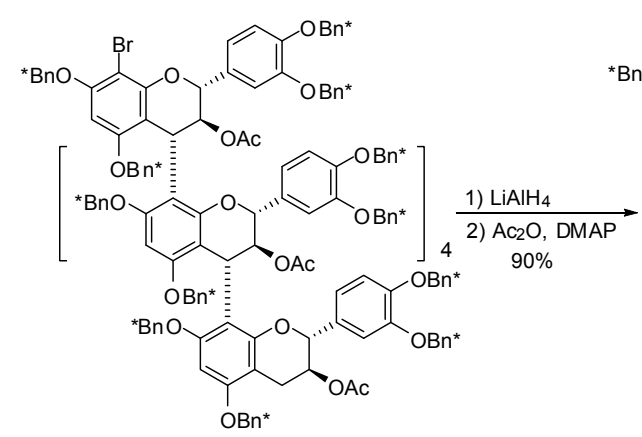

75

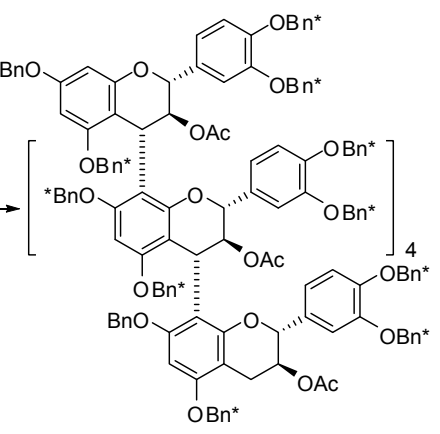

83

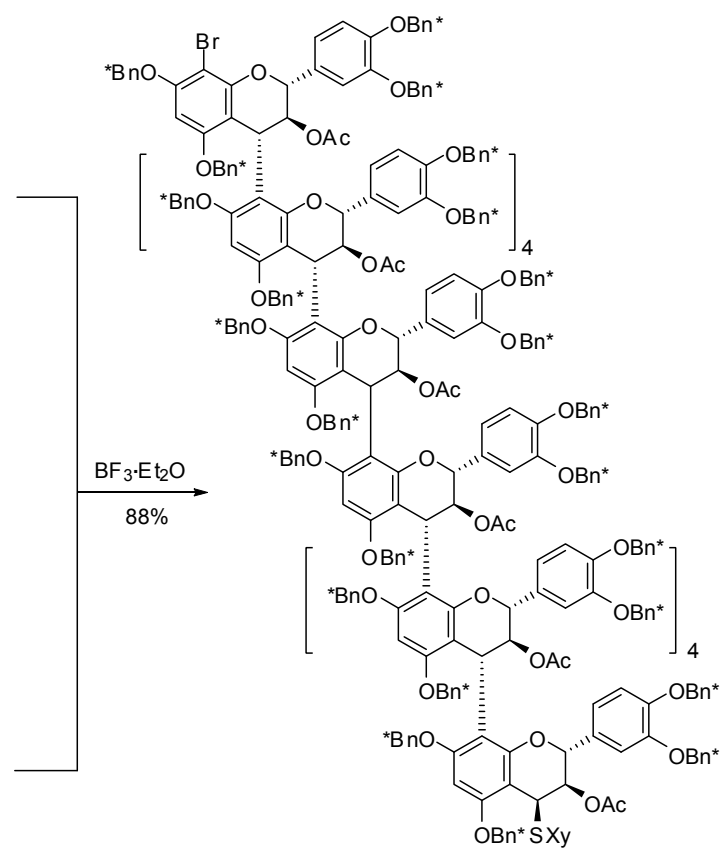

82

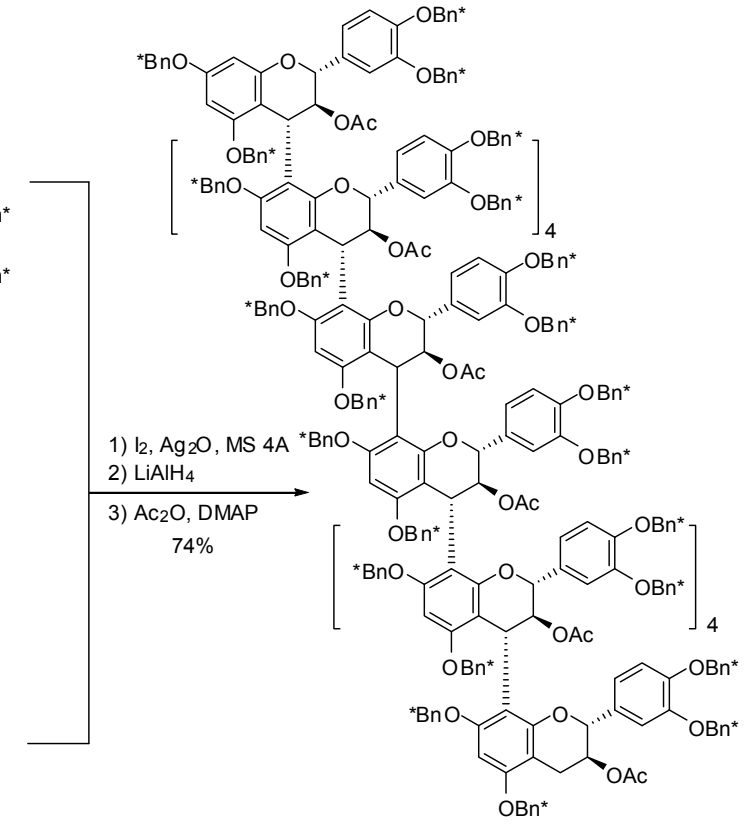

84

Scheme 17. Synthesis of catechin dodecamers by the $\{6+6\}$ coupling using orthogonal strategy 
Finally, the condensation between dodecamers 82 and $\mathbf{8 4}$ using $\mathrm{I}_{2}$ and $\mathrm{Ag}_{2} \mathrm{O}$ gave desired tetracosamer $\mathbf{8 5}$ cleanly in $80 \%$ yield (Scheme 18).

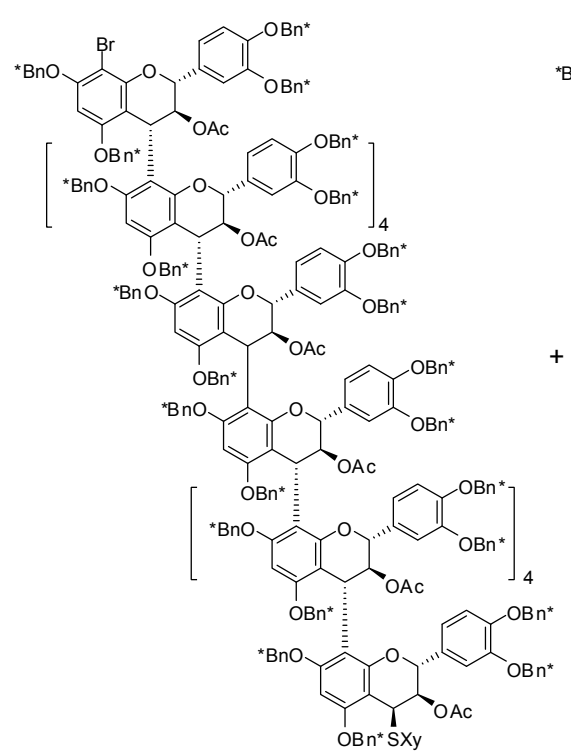

82

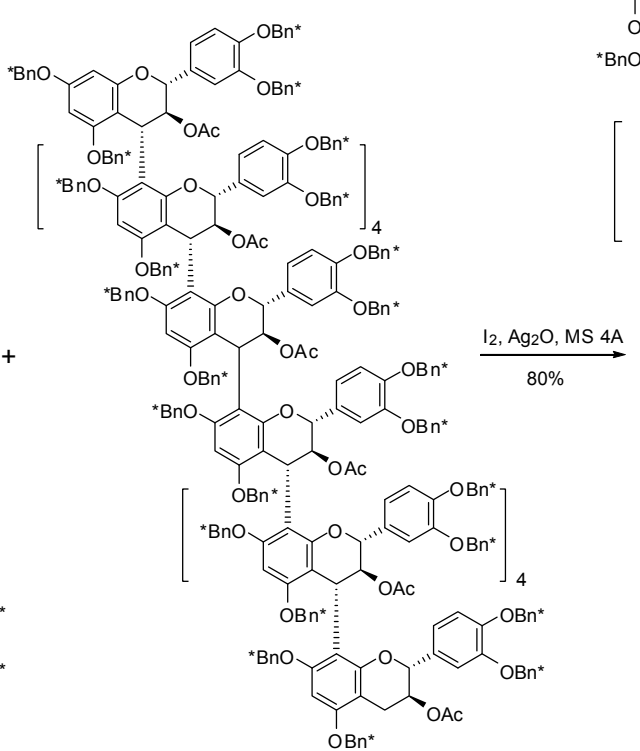

84
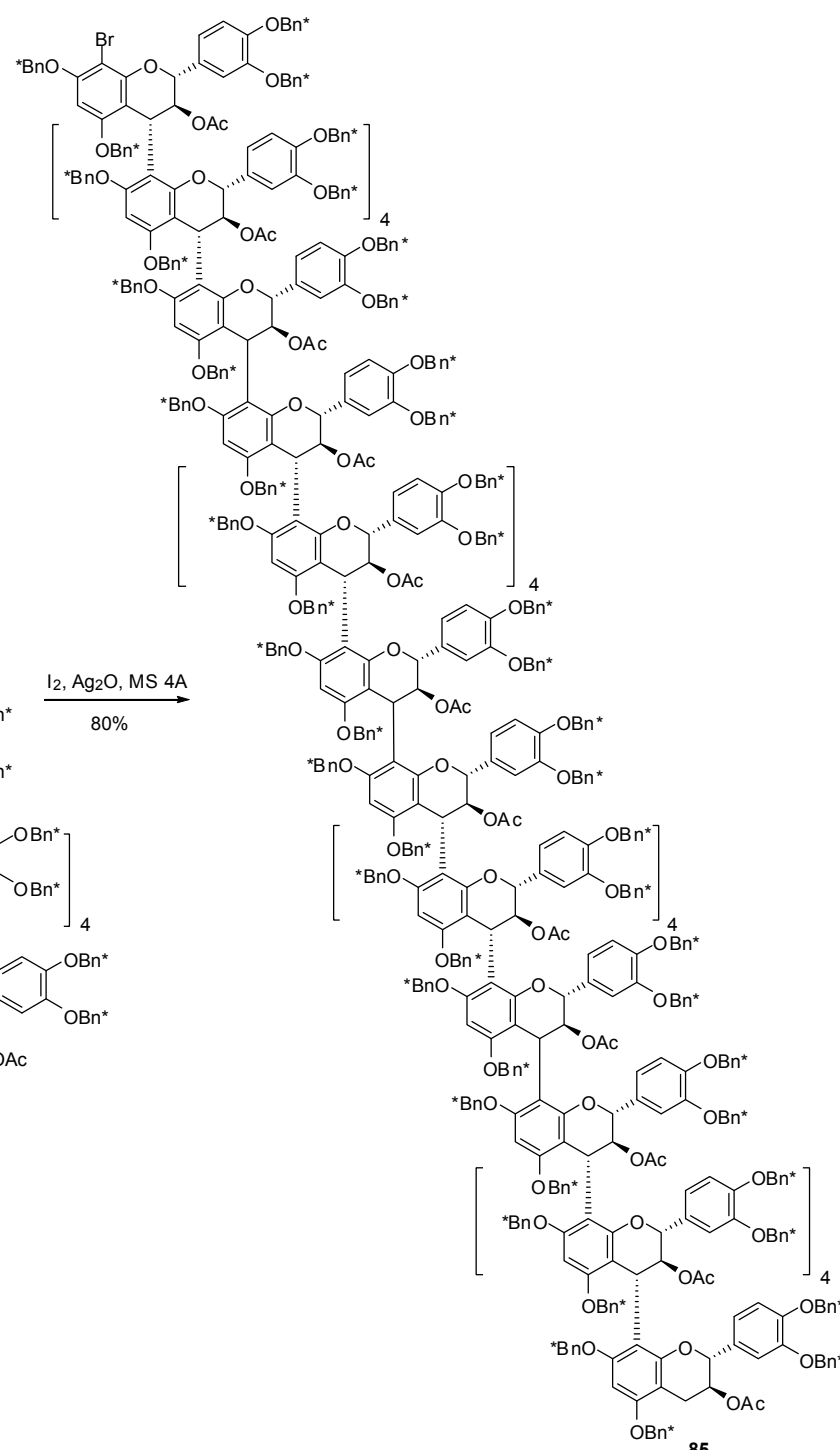

Scheme 18. Synthesis of protected catechin tetracosamer $\mathbf{8 5}$ using $\{12+12\}$ coupling

\section{SYNTHESIS OF PRODELPHINIDINS}

As describes above, many examples of the syntheses of procyanidins were reported in this decade including our syntheses, however, synthetic studies on prodelphinidins are quite limited due to the difficulty in obtaining (-)-gallocatechin or $(+)$-epigallocatechin as synthetic starting materials. ${ }^{36}$ Until now only an example of total synthesis of prodelphinidin B3 (14) and C2 (16) has been reported by Makabe and co-workers using equimolar coupling between nucleophilic and electrophilic partners in the presence of Lewis acid. ${ }^{5}$ The gallocatechin-derived building block $\mathbf{8 8}$ was constructed as Chan and 
co-workers reported with slight modification. ${ }^{37}$ DDQ oxidation in the presence of methanol or ethoxyethanol gave electrophiles $\mathbf{8 9}$ and $\mathbf{9 0}$, respectively (Scheme 19).

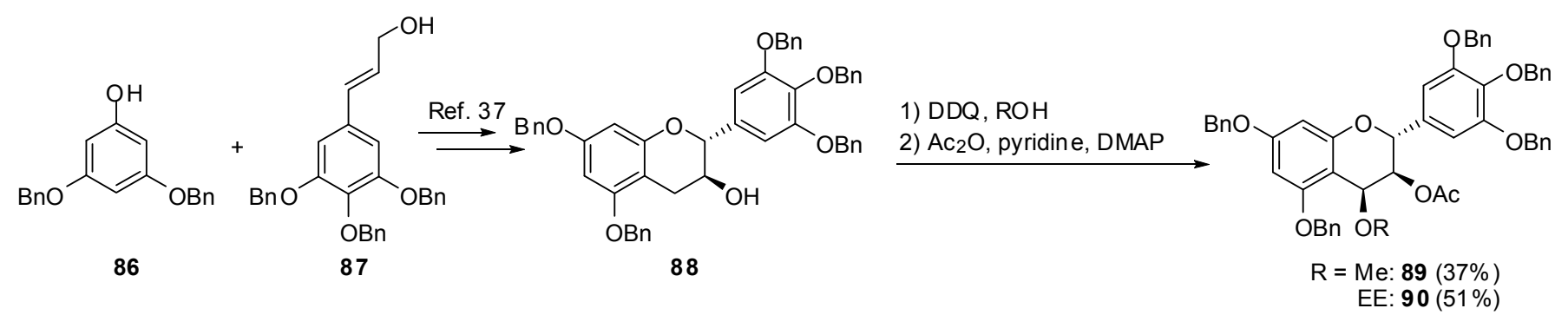

Scheme 19. Synthesis of gallocatechin nucleophile and electrophile

They examined the condition of equimolar condensation of catechin nucleophile $\mathbf{1 7}$ with gallocatechin electrophile 89 or 90. As shown in Table 4, 4-(2"-ethoxyethoxy) derivative 90 afforded condensed product in good yield when $\mathrm{Yb}(\mathrm{OTf})_{3}$ was used as Lewis acid. On the other hand, using methoxy derivative 89 gave 91 in very low yield. The choice of leaving the group at the C-4 position was important in this condensation (Table 4).

Table 4. Equimolar condensation of gallocatechin electrophile 89 or $\mathbf{9 0}$ with catechin nucleophile $\mathbf{1 7}$

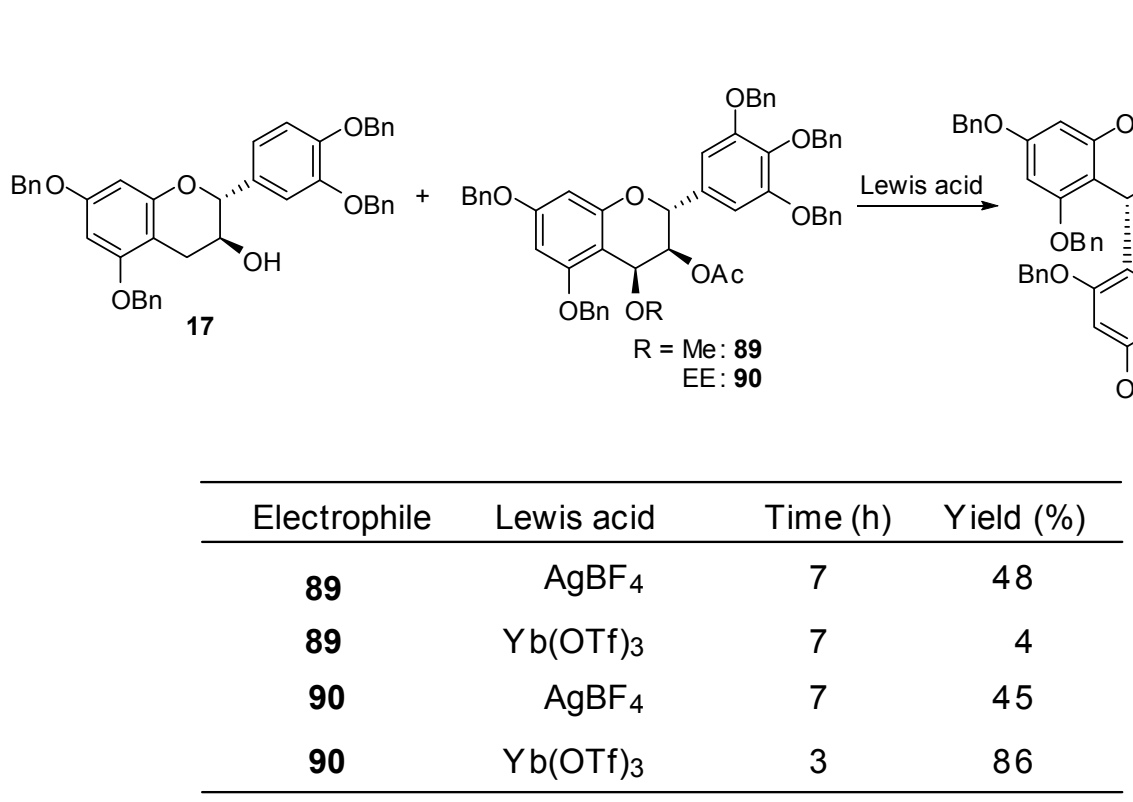

${ }^{a}$ The reaction was carried out in $\mathrm{CH}_{2} \mathrm{Cl}_{2}$ at room temperature.

The condensed product 91 was transformed into diol 92 using $n-\mathrm{Bu}_{4} \mathrm{NOH}$, subsequent deprotection of the benzyl ethers of 92 afforded prodelphinidin B3 (14) in good yield. The ${ }^{1} \mathrm{H}$ NMR spectral data of peracetate 93 was in good agreement with that of the reported value (Scheme 20). ${ }^{31}$ 


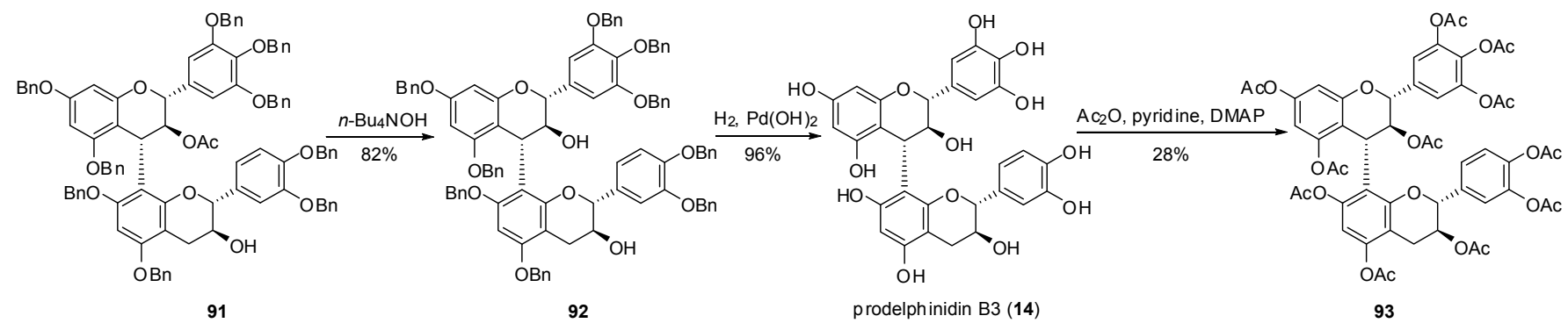

Scheme 20. Synthesis of prodelphinidin B3 (14) and its peracetate 93

Diol 92 was used as a nucleophile for the synthesis of prodelphinidin C2 (16). They examined equimolar condensation of 92 with electrophile 89 or $\mathbf{9 0}$. The authors have found that silver Lewis acids were effective for the construction of catechin trimer derivatives. ${ }^{28,29}$ Thus they used $\mathrm{AgBF}_{4}$ and $\mathrm{AgOTf}$ as Lewis acid, respectively. As shown in Table 5, the 4-methoxy derivative $\mathbf{8 9}$ afforded condensed product 94 in good yield when AgOTf was used. The reaction using $\mathrm{AgBF}_{4}$ as Lewis acid and 4-methoxy derivative 89 as an electrophile afforded 94 in poor yield. The combination of the C-4 leaving group and silver Lewis acid was very important (Table 5).

Table 5. Condensation of gallocatechin electrophile 89 or 90 with nucleophile $\mathbf{9 2}^{\mathrm{a}}$

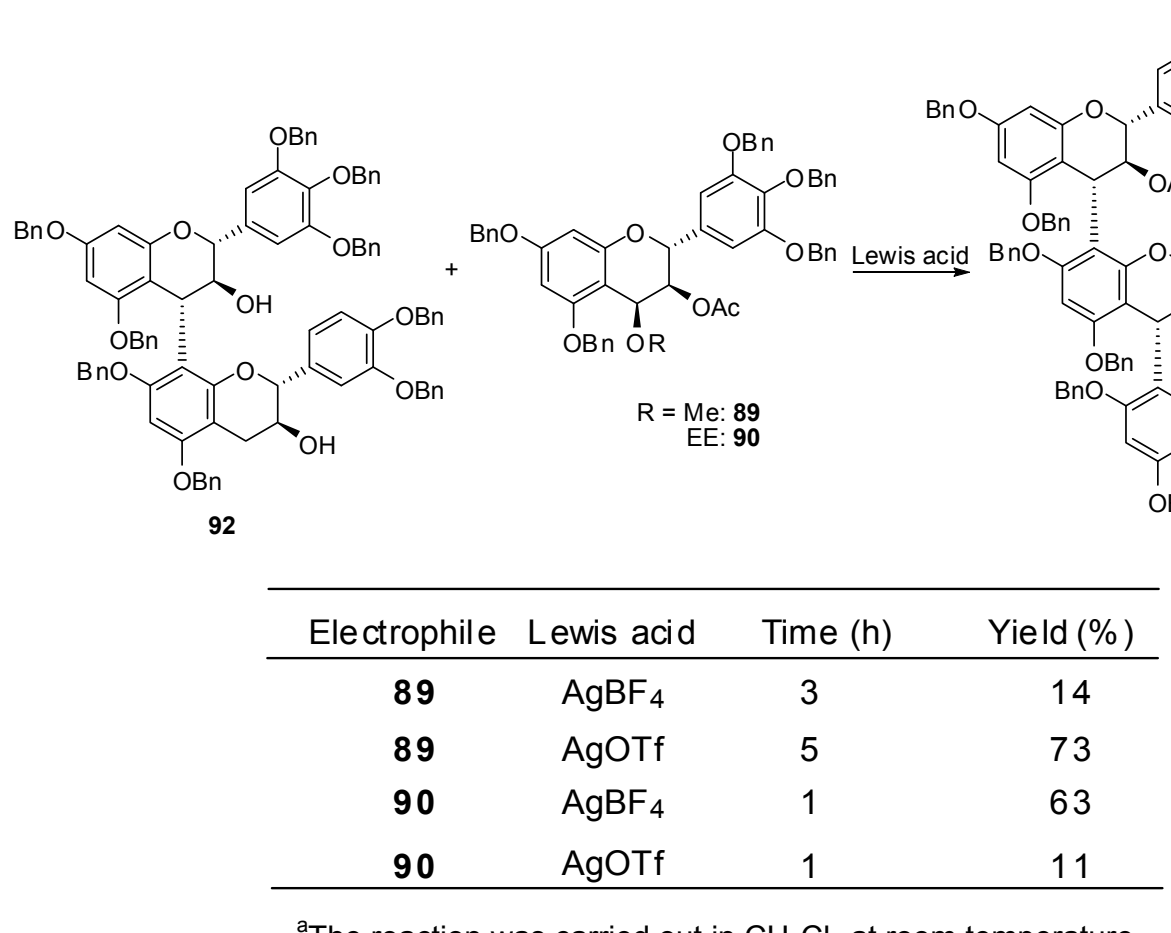

${ }^{\mathrm{a}}$ The reaction was carried out in $\mathrm{CH}_{2} \mathrm{Cl}_{2}$ at room temperature.

The condensed product 94 was transformed into triol 95 using $n$ - $\mathrm{Bu}_{4} \mathrm{NOH}^{32}$ Finally deprotection of the benzyl ethers of 95 and subsequent lyophilization afforded prodelphinidin $\mathrm{C} 2$ (16) in good yield. The ${ }^{1} \mathrm{H}$ NMR spectral data of peracetate 96 was in good agreement with that of the reported value (Scheme 21). ${ }^{31}$ 


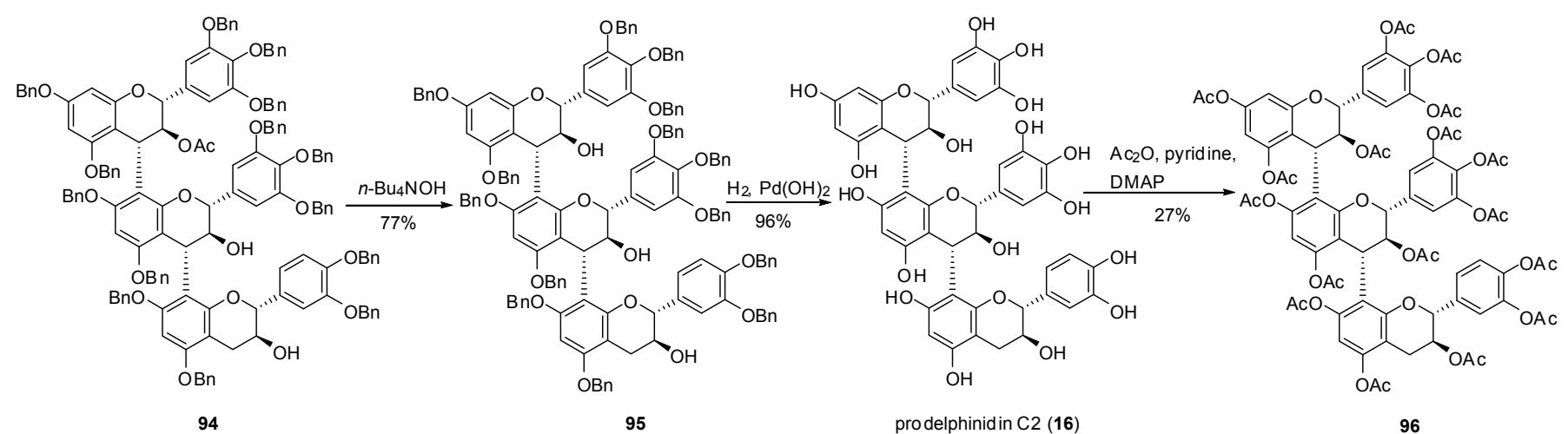

Scheme 21. Synthesis of prodelphinidin C2 (16) and its peracetate 96

The authors examined the antitumor activities of synthesized prodelphinidins B3 (14) and C2 (16) against PC-3 prostate cancer cell lines together with procyanidin B3 (3), C1 (6) and C2 (7) which were prepared by same group (Figure 4).<smiles>O=C(O)C1Cc2c(O)cc(O)cc2O[C@H]1c1cc(O)c(O)c(O)c1</smiles>

epigallo catechin-gallate (EGCG)<smiles></smiles>

procyanidin $\mathrm{B} 3(\mathrm{PCB} 3,3)$<smiles>Oc1cc(O)c2c(c1)O[C@H](c1cc(O)c(O)c(O)c1)[C@H](O)[C@H]2c1cc(O)cc(O)c1C[C@@H](O)c1ccc(O)c(O)c1</smiles>

prodelphin idin B3 (PDB3,14)<smiles>Oc1cc(O)c2c(c1)O[C@H](c1ccc(O)c(O)c1)[C@H](O)C2c1c(O)cc(O)c2c1O[C@H](c1ccc(O)c(O)c1)[C@H](O)C2c1c(O)cc(O)c2c1O[C@H](c1ccc(O)c(O)c1)[C@H](O)C2</smiles>

procyanid in $\mathrm{C} 1(\mathrm{PCC} 1,6)$<smiles>Oc1cc(O)c2c(c1)O[C@H](c1ccc(O)c(O)c1)[C@H](O)[C@H]2c1c(O)cc(O)c2c1O[C@H](c1ccc(O)c(O)c1)[C@H](O)[C@H]2c1c(O)cc(O)c2c1O[C@H](c1ccc(O)c(O)c1)[C@H](O)C2</smiles>

procyanidin $\mathrm{C} 2(\mathrm{PCC} 2,7)$

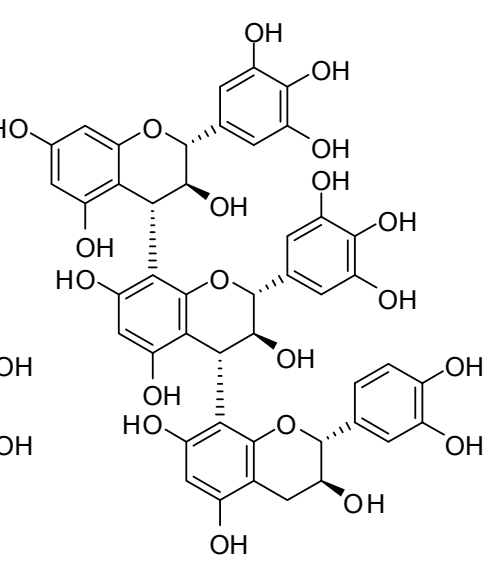

prodelphinidin C2 (PDC2, 16)

Figure 4. The structures of test compounds for PC-3 prostate anticancer activity

Results were obtained by two independent methods: cell count measurement and MTT assay. Epigallocatechin gallate (EGCG), which is well known as an antitumor agent, was used as a positive control. As shown in Figure 4, EGCG, prodelphinidin B3 (14) and C2 (16) exhibited significant cytotoxic 
activity with $\mathrm{IC}_{50}$ values below $50 \mu \mathrm{M}$. Making a comparison of the potencies of $\mathbf{1 4}$ with procyanidin $\mathrm{B} 3$ (3), suggested that the cytotoxic effects were clearly associated with the presence of the pyrogallol moiety. The PDB3 (14) and PCB3 (3) have the same carbon skeleton. The only difference is that PDB3 (14) has an additional hydroxy group at the B ring. The authors showed that this hydroxy group greatly affected the cytotoxic effect. As for 16 and procyanidin C1 (6) or C2 (7), the data showed that the pyrogallol moiety was essential for their activity. This tendency was also observed in the MTT assay. These findings might be useful in searching for antitumor compounds among the proanthocyanidins (Figure 5).

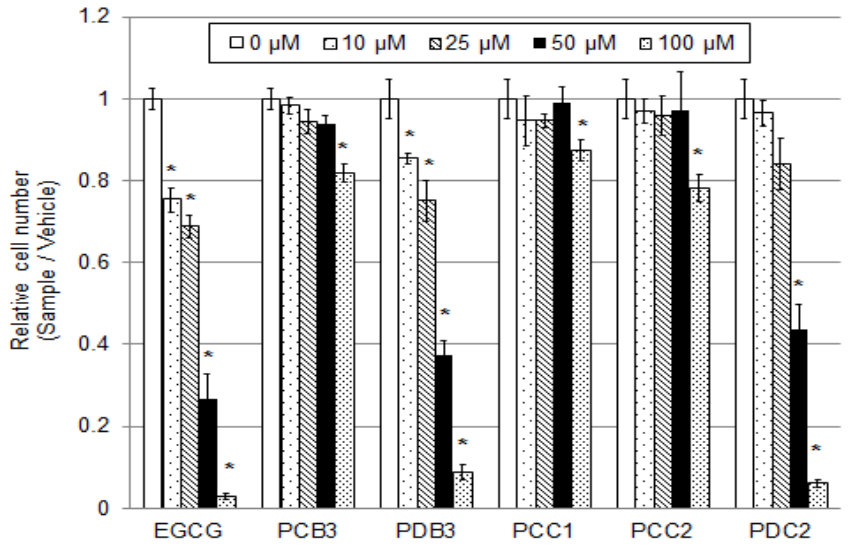

(A)

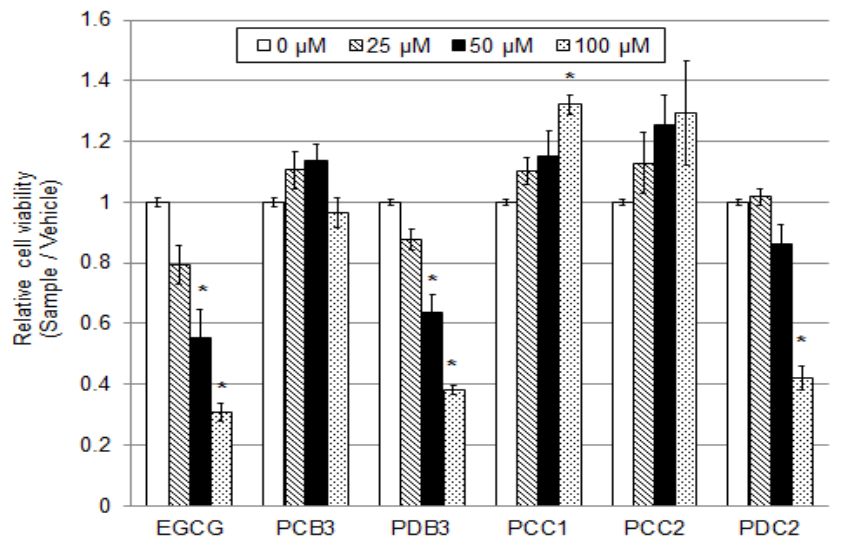

(B)

Figure 5. Effects of various concentrations of test compounds on cell proliferation using cell count (A) and MTT assay (B). After treatment of cells with EGCG, PCB3, PCC1, PCC2, PDB3, PDC2, or CPT for $48 \mathrm{~h}$, the cell proliferation was determined by cell count (A) and MTT assay (B). The values were represented as the rate of inhibition of cell proliferation by the treated sample compared to the untreated control (vehicle). Values are means \pm S.Ds. for three independent experiments. Asterisks indicated a significant difference between the control- and test-compound-treated cells, as analyzed by Student's test $(\mathrm{p}<0.001)$.

\section{CONCLUSION}

Proanthocyanidins have been paid attention to the synthetic and biological researchers due to their unique structures and significant biological activities. Synthetic efforts toward proanthocyanins have performed mainly using condensation of C-4 to C-8 flavan bonds. Flavan-3-ols as nucleophiles and flavan-3,4-diols and its derivatives were subjected for the condensation in the presence of a Lewis acid. Recent progress of this reaction made a regio- and stereoselective synthesis of proanthocyanidin oligomers in good yield. However, there is still much room to develop synthetic methodologies especially for the highly polymerized proanthocyanidins. When synthetic methods of this complex molecule will be fully developed, proanthocyanidins will be candidate drugs for treating various diseases. 


\section{REFERENCES (AND NOTES)}

1. D. Ferreira and X.-C. Li, Nat. Prod. Rep., 2000, 17, 193.

2. D. Ferreira and X.-C. Li, Nat. Prod. Rep., 2002, 19, 517.

3. N. Seeram, M. Aviram, Y. Zhang, S. M. Hennings, L. Feng, M. Dreher, and D. Heber, J. Agric. Food Chem., 2008, 56, 1415.

4. S. Mitsuhashi, A. Saito, N. Nakajima, H. Shima, and M. Ubukata, Molecules, 2008, 13, 2998.

5. W. Fujii, K. Toda, K. Kawaguchi, S.-i. Kawahara, M. Katoh, Y. Hattori, H. Fujii, and H. Makabe, Tetrahedron, 2013, 69, 3543.

6. H. Y. Cheng, T. C. Lin, C. M. Yang, D. E. Shieh, and C. C. Lin, J. Sci. Food Agric., 2005, 85, 10.

7. X. Terra, J. Valls, X. Vitrac, J. M. Merrillon, L. Arola, A. Ardevol, C. Blade, J. Fernandez-Larrea, G. Pujadas, J. Salvado, and M. Blay, J. Agric. Food Chem., 2007, 55, 4357.

8. A. Saito, M. Emoto, A. Tanaka, Y. Doi, K. Shoji, Y. Mizushina, H. Ikawa, H. Yoshida, N. Matsuura, and N. Nakajima, Tetrahedron, 2004, 60, 12043.

9. D. Ferreira and C. M. Coleman, Planta Med., 2011, 77, 1071.

10. K-i. Oyama, K. Yoshida, and T. Kondo, Curr. Org. Chem., 2011, 15, 2567.

11. K. Ohmori and K. Suzuki, Curr. Org. Chem., 2012, 16, 566.

12. A. P. Kozikowski, W. Tückmantel, G. Böttcher, and L. J. Romanczyk, Jr., J. Org. Chem., 2003, 68, 1641.

13. P. W. Caton, M. R. Pothecary, D. M. Lees, N. Q. Khan, E. G. Wood, T. Shoji, T. Kanda, G. Rull, and R. Corder, J. Agric. Food Chem., 2010, 58, 4008.

14. L. L. Creasy and T. Swain, Nature, 1965, 208, 151.

15. H. Kawamoto, F. Nakatubo, and K. Murakami, Mokuzai Gakkaishi, 1991, 37, 488.

16. A. Saito, N. Nakajima, A. Tanaka, and M. Ubukata, Tetrahedron, 2002, 58, 7829.

17. A. Saito, N. Nakajima, A. Tanaka, and M. Ubukata, Biosci. Biotechnol. Biochem., 2002, 66, 1764.

18. A. Saito, N. Nakajima, N. Matsuura, A. Tanaka, and M. Ubukata, Heterocycles, 2004, 62, 479.

19. A. Saito, Y. Mizushina, H. Ikawa, H. Yoshida, Y. Doi, A. Tanaka, and N. Nakajima, Bioorg. Med. Chem., 2005, 13, 2759.

20. Y. Mohri, M. Sagehashi, T. Yamada, Y. Hattori, K. Morimura, T. Kamo, M. Hirota, and H. Makabe, Tetrahedron Lett., 2007, 48, 5891.

21. Y. Mohri, M. Sagehashi, T. Yamada, Y. Hattori, K. Morimura, Y. Hamauzu, T. Kamo, M. Hirota, and H. Makabe, Heterocycles, 2009, 79, 549.

22. M. Suda, M. Katoh, K. Toda, K. Matsumoto, K. Kawaguchi, S.-i. Kawahara, Y. Hattori, H. Fujii, and H. Makabe, Bioorg. Med. Chem. Lett., 2013, 23, 4935.

23. G. Watanabe, K. Ohmori, and K. Suzuki, Chem. Commun., 2013, 49, 5210. 
24. A. Saito, A. Tanaka, M. Ubukata, and N. Nakajima, Synlett, 2004, 1069.

25. A. Saito, Y. Doi, A. Tanaka, N. Matsuura, M. Ubukata, and N. Nakajima, Bioorg. Med. Chem., 2004, 12,4783 .

26. K. Ohmori, N. Ushimaru, and K. Suzuki, Proc. Natl. Acad. Sci. USA, 2004, 101, 12002.

27. T. Yano, K. Ohmori, H. Takahashi, T. Kusumi, and K. Suzuki, Org. Biol. Chem., 2012, 10, 7685.

28. Y. Oizumi, Y. Mohri, Y. Hattori, and H. Makabe, Heterocycles, 2011, 83, 739.

29. Y. Oizumi, M. Katoh, Y. Hattori, K. Toda, K. Kawaguchi, H. Fujii, and H. Makabe, Heterocycles, $2012,85,2241$.

30. P. J. Steynberg, R. J. J. Nel, H. van Rensberg, B. C. B. Bezuidenhoudt, and D. Ferreira, Tetrahedron, 1998, 54, 8153.

31. J. A. Delcour and S. A. R. Vercruysse, J. Inst. Brew., 1986, 92, 244.

32. A. P. Kozikowski, W. Tückmantel, G. Böttcher, and L. J. Romanczyk, Jr., J. Org. Chem., 2003, 68, 1641.

33. A. Saito, Y. Mizushina, A. Tanaka, and N. Nakajima, Tetrahedron, 2009, 65, 7422.

34. K. I. Oyama, M. Kuwano, M. Ito, K. Yoshida, and T. Kondo, Tetrahedron Lett., 2008, 49, 3176.

35. K. Ohmori, T. Shono, Y. Hatakoshi, T. Yano, and K. Suzuki, Angew. Chem. Int. Ed., 2011, 50, 4862 .

36. K. Krohn, I. Ahmed, M. John, M. C. Letzel, and D. Kuck, Eur. J. Org. Chem., 2010, 2544.

37. S. B. Wan, Q. P. Dou, and T. H. Chan, Tetrahedron, 2006, 62, 5897.

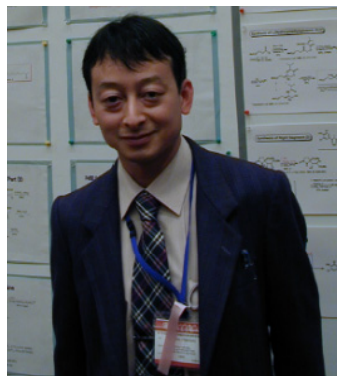

Professor Hidefumi Makabe was obtained his Ph. D. degree in 1997 from Tohoku University. He joined the Department of Chemistry, Purdue University as a JSPS postdoctoral fellow from 1997 to 1999. In 1999, he joined the Faculty of Agriculture, Shinshu University as an assistant professor. In 2001, he was promoted to associate professor at the same university. In 2012, he was promoted to professor. He was awarded The Japan Bioscience, Biotechnology and Agrochemistry Society Award for the Encouragement of Young Scientists in 2006. His research interest is in the area of organometallic chemistry toward synthesis of natural products and the structural activity relationship study of bioactive natural products. 